(C) 2021, The Authors. Published by Elsevier Inc. and Fass Inc. on behalf of the American Dairy Science Association ${ }^{\circledR}$. This is an open access article under the CC BY-NC-ND license (http://creativecommons.org/licenses/by-nc-nd/4.0/).

\title{
Aspects of transition cow metabolomics-Part II: Histomorphologic changes in the liver parenchyma throughout the transition period, in cows with different liver metabotypes and effects of a metaphylactic butaphosphan and cyanocobalamin treatment
}

\author{
F. Pietsch, ${ }^{1}$ M. Schären, ${ }^{1 *}$ T. Snedec, ${ }^{1}$ K. B. Theinert, ${ }^{1}$ A.-S. Leonhardt, ${ }^{1}$ A. Kaiser, ${ }^{1}$ F. Rachidi, ${ }^{1}$ D. Böttcher, ${ }^{2}$ \\ J. Scheinert, ${ }^{2}$ H.-A. Schoon, ${ }^{2}$ P. Wohlsein, ${ }^{3}$ J. Spilke, ${ }^{4}$ A. Haudum, ${ }^{5}$ W. Baumgartner, ${ }^{6}$ and A. Starke ${ }^{1}$ \\ ${ }^{1}$ Clinic for Ruminants and Swine, Faculty of Veterinary Medicine, Leipzig University, An den Tierkliniken 11, 04103 Leipzig, Germany \\ ${ }^{2}$ Institute of Veterinary Pathology, Faculty of Veterinary Medicine, Leipzig University, An den Tierkliniken 33, 04103 Leipzig, Germany \\ ${ }^{3}$ Department of Pathology, University of Veterinary Medicine Hanover, Foundation, Bünteweg 17, 30559 Hanover, Germany \\ ${ }^{4}$ Biometrics and Informatics in Agriculture Group, Institute of Agricultural and Nutritional Sciences, Martin-Luther University, Halle-Wittenberg, Karl- \\ Freiherr-von-Fritsch-Str. 4, 06108 Halle (Saale), Germany \\ ${ }^{5}$ Veterinary Practice, Herrnschlag 3, 4170 St. Stefan am Walde, Austria \\ ${ }^{6}$ University Clinic for Ruminants, University of Veterinary Medicine, Veterinärplatz 1, 1210 Vienna, Austria
}

\begin{abstract}
The aims of this study were to evaluate histopathologic changes during the transition period, describe the histopathological features of the metabotypes identified in Part I (Schären et al., 2021b), and investigate effects of a metaphylactic treatment with butaphosphan and cyanocobalamin (BCC) on the liver parenchyma. Eighty German Holstein cows (mean 305-d production: 10,957 $\mathrm{kg}$, range: 6,480-15,193 kg; mean lactation number: 3.9, range: 2-9) from a commercial dairy farm in Saxony, Germany, were enrolled in a randomized, prospective, triple-blinded study. Two groups received a treatment with BCC (5 or $10 \mathrm{~mL} / 100 \mathrm{~kg}$ of body weight $10 \%$ butaphosphan and $0.005 \%$ cyanocobalamin, Catosal, Bayer Animal Health, $\mathrm{n}=20$ each) and one group a placebo treatment $(\mathrm{NaCl} 0.9 \%, \mathrm{n}=40)$. Liver biopsy specimens were collected $14 \mathrm{~d}$ antepartum (AP) and 7,28 , and $42 \mathrm{~d}$ postpartum (PP), routinely processed for histologic examination, and stained with hematoxylin and eosin, Sudan III, periodic acid-Schiff, and picrosirius red stains. The sections were assessed for fat and glycogen content and degenerative, inflammatory, fibrotic, and proliferative changes. The statistical analysis included the effects of the sampling day, the lactation number, the treatment, and the metabotype $(\mathrm{A}=$ medium, $\mathrm{B}=$ minor, $\mathrm{C}=$ large alterations in the liver metabolome profile between AP and PP status).
\end{abstract}

Received June 9, 2020.

Accepted March 18, 2021.

*Corresponding author: melanie.schaeren@vetmed.uni-leipzig.de
There was mild to moderate fat infiltration in the liver of $37 \%$ of cows in the last 2 wk AP, and moderate to severe fat infiltration in $66 \%$ of cows in the first days PP. The degree of fat infiltration increased from 2 wk AP until the end of the first week PP, and then decreased until the end of the study period, at which time about $25 \%$ of cows had moderate to severe fatty infiltration. Lipidosis was positively correlated with the severity of liver cell degeneration, and negatively correlated with the degree of glycogen deposits. Complete glycogen depletion of hepatocytes was not observed in cows, even in the presence of severe hepatic lipidosis. Moderate to severe lymphocytic hepatitis was seen in $39 \%$ of cows throughout the study period, and cows with lactation numbers 5 or greater had perisinusoidal fibrosis more often than younger cows. Severe fibrosis and cirrhosis of the liver did not occur. Metabotype B animals exhibited a higher chance of fatty infiltration, lower glycogen storage, and perisinusoidal fibrosis and for this metabotype positive correlations were calculated between increased fat deposition in the liver and marked glycogen depletion, and increased degenerative, inflammatory, fibrotic, and proliferative changes of hepatic tissue. For the treatment with BCC, no significant effect was observed. In summary, during the transition period, the liver of dairy cows is characterized by fat accumulation and glycogen depletion and histologic signs of hepatitis and hepatocyte degeneration. These histomorphologic changes were accentuated in animals exhibiting little alterations in their liver metabolome profile across the transition period (metabotype B) and support the assumption of a decreased grass silage quality as a causative factor.

Key words: fatty liver, fibrosis, glycogen, hepatitis 


\section{INTRODUCTION}

Moderate to severe hepatic lipidosis (fatty liver) may occur in 40 to $66 \%$ of dairy cows during early lactation (Reid, 1980; Gerloff et al., 1986; Jorritsma et al., 2001). The risk of liver failure in cows has been shown to increase up to 5.3-fold with increasing fat content (Rehage et al., 1996). Hepatic fatty infiltration, liver cell degeneration (Reid, 1980; Reid and Collins, 1980; Johannsen et al., 1988), and the infiltration of reactive inflammatory cells (Fürll, 1989; Mertens, 1992) were thought to be interrelated and result in impaired liver function.

In addition to fat, glycogen plays an important role in the metabolism of dairy cows, providing a readily available source of energy (Gardner et al., 2014). Unlike monogastric animals, hepatic gluconeogenesis is crucial for glucose metabolism in ruminants (Herdt, 1988; Aschenbach et al., 2010). Cows are therefore capable of meeting about $75 \%$ of daily energy demands with the ruminal production of VFA, including acetate, propionate, and butyrate (65:20:15; Bergman, 1990). However, the energy demand of high-producing dairy cows constitutes a considerable challenge. In addition to about $200 \mathrm{~g}$ of glucose required for maintenance, the daily production of 40 to $50 \mathrm{~kg}$ of milk requires another approximately $3.8 \mathrm{~kg}$ of glucose (Elliot, 1976), which is an enormous demand on the liver in terms of gluconeogenesis and illustrates the role of glycogen as a critical energy substrate and reserve.

We are not aware of current studies on the concurrent dynamic of fat and glycogen metabolism in terms of histomorphologic and histochemical changes in the liver of dairy cows during the transition period and their interrelation with inflammatory, fibrotic, and proliferative changes. Therefore, in the scope of a large study, investigating pathomechanisms of the fatty liver syndrome in dairy cows, multiple liver biopsies were collected in 80 German Holstein cows throughout the transition period. Aside the sound documentation and interrelation of the production state, clinical traits and liver pathohistological features, the trial design and aims included the interrelation of these data with the liver and blood metabolome and the investigation of the effects of a metaphylactic treatment with butaphosphan and cyanocobalamin (BCC, described in detail in Part I; Schären et al., 2021b).

Hence, the aims of Part II of the study presented here were to (1) describe liver histopathological alterations across the transition period, regarding fat and glycogen storage, as well as degenerative, inflammatory, fibrotic, and proliferative changes, with a particular interest on whether a relationship exists between the dynamics of fat storage and the concurrent depletion of glycogen,
(2) investigate the histopathological features of the liver metabotypes identified in Part I (Schären et al., 2021b), and (3) investigate effects of a metaphylactic treatment with $\mathrm{BCC}$ on the liver parenchyma.

\section{MATERIALS AND METHODS}

\section{Study Design}

The study design is described in detail in Materials and Methods of Part I (Schären et al., 2021b). In summary, an on-farm randomized, prospective, tripleblinded study was performed on a 660-cow dairy in Saxony, Germany, between November 23, 2015, and December 3, 2016. The cows were housed in a freestall system with deep bedding boxes (except for a part of the dry period) and received a TMR-based (grass- and corn-silage as main components) ration. The herd was characterized by a rolling average milk production of $10,747 \mathrm{~kg}$ and fat and protein contents of 3.73 and $3.33 \%$, respectively [official monthly milk control report by the local state control association (Landeskontrollverband, Sachsen) on December 5, 2016]. Eighty animals in second or higher lactation were included in the study and followed from $14 \mathrm{~d}$ antepartum (AP, expected calving date) until $49 \mathrm{~d}$ postpartum $(\mathbf{P P})$, with a thorough and close documentation of the production and clinical traits and clinical chemistry. Their average lactation number was 3.9 (range: 2-9, lactation number at calving in trial), the BCS was 2.91 [range: 2.00-3.75; $14 \mathrm{~d}$ AP, according to 5-point scale of Edmonson et al. (1989)] and the 305-d milk production in previous lactation was $10,957 \mathrm{~kg}$ (range: $6,480-15,193$ ). To analyze a possible effect of age, the cows were allocated to one of 3 lactation groups: second lactation (L1), third and fourth lactations (L2), and fifth and higher lactations (L3).

To evaluate a metaphylactic treatment protocol with butaphosphan and cyanocobalamin, the following treatment groups were established: 2 groups with a Catosal treatment (Bayer Animal Health $\mathrm{GmbH}$ ) with the recommended dose (as registered in Germany) of 5 $\mathrm{mL} / 100 \mathrm{~kg}$ of BW (VER5, $\mathrm{n}=20$, parity: $4.2 \pm 2.0$, mean $\pm \mathrm{SD}$ ) or the double dose of $10 \mathrm{~mL} / 100 \mathrm{~kg}$ of BW (VER10, $\mathrm{n}=20$, parity: $3.4 \pm 1.3$ ), and 2 placebo groups with 5 or $10 \mathrm{~mL}$ of $\mathrm{NaCl} 0.9 \% / 100 \mathrm{~kg}$ of $\mathrm{BW}$ (for analysis, the 2 groups were merged to one control group, $\mathbf{C O N}, \mathrm{n}=40$, parity: $4.0 \pm 1.9)$. The group assignment occurred randomly using a lottery procedure. The animals were treated at 6 time points: 7,6 , and 5 $\mathrm{d}$ AP, and 1, 2, and $3 \mathrm{~d} \mathrm{PP}$.

Three different metabotypes were identified in a follow-up analysis based on their metabolic alterations in the liver over the course of the transition period 
[based on patterns observed in the partial least squares discriminant analysis (PLS-DA) plots of the liver metabolome, $\mathrm{A}=$ medium, $\mathrm{B}=$ minor, $\mathrm{C}=$ large alterations in the liver metabolic profiles between AP and PP status, details in Part I; Schären et al., 2021]. It was further discovered that the metabotypes corresponded with the time the animals entered the study: animals calving in either period A: November 23, 2015 to February 6, $2016(\mathrm{n}=15)$, B: February 7 to May 31, 2016 $(\mathrm{n}=28)$, or C: June 1 to December 3, $2016(\mathrm{n}=37)$. The treatment groups (VER5, VER10, and CON) were almost equally distributed within the metabotypes (A: $\mathrm{n}=6,4$, and $5 ; \mathrm{B}: \mathrm{n}=13,8$, and $7 ; \mathrm{C}: \mathrm{n}=19,10$, and 8 for VER5, VER10, and CON, respectively). Metabotype $\mathrm{B}$ animals were characterized by: lower milk protein percentage and higher milk fat percentage, higher $\mathrm{AP}$ and stronger peripartum decrease in BCS, higher risk to be diseased, and higher PP blood bilirubin, fatty acids, gamma-glutamyltransferase, and triglyceride levels. Reasons for this increased lipomobilization and clinical sequelae presumably lie in a decreased grass silage quality fed in this period (elaborated in the discussion of Part I; Schären et al., 2021).

\section{Liver Biopsies and Sample Preparation}

Each cow underwent 4 liver biopsy procedures at 14 $\mathrm{d} \mathrm{AP}$ and 7,28 , and $42 \mathrm{~d} \mathrm{PP}$ using the technique described by Gohlke et al. (2013). Difficulty in predicting parturition, variable farm management schedules, and the high workload demands on the operators resulted in deviations from the scheduled sampling days; T1: mean $12 \mathrm{~d}$ AP, range 1 to $26 \mathrm{~d}$; T2: mean $7 \mathrm{~d}$ PP, range 4 to $13 \mathrm{~d}$; T3: mean $28 \mathrm{~d}$ PP, range 23 to $34 \mathrm{~d}$; and T4: mean $42 \mathrm{~d}$ PP, range 37 to $50 \mathrm{~d}$. The deviations from the sampling protocol were taken into account during statistical analysis.

\section{Sample Preparation}

The samples of fresh liver tissue were carefully rinsed with sterile isotonic saline solution $(0.9 \%$ sodium chloride solution; Serumwerk Bernburg AG), and any remaining blood was removed with sterile gauze pads. The liver samples were cut into $0.5 \times 0.5 \times 2 \mathrm{~cm}$ pieces using a scalpel blade and a minimal amount of pressure to avoid crushing the tissue. Two pieces were placed in $4 \%$ neutral buffered formaldehyde solution, and one piece was placed in $96 \%$ ethanol for a minimum of 24 hours. The samples were stored in the fixative solutions at room temperature in the dark.

One aliquot of formaldehyde-fixed tissue was routinely processed for histologic evaluation (Kabisch et al., 2019) and stained with hematoxylin and eosin (HE) according to Mayer (1920) and picrosirius red (PSR) according to Constantine (1969) and modified by Grüninger (1996). A cryotome (Reichert-Jung) was used to cut the second sample of formaldehyde-fixed tissue into 10 - to $12-\mu \mathrm{m}$ sections, which were stained with Sudan III-hematoxylin (SIII; Riedelsheimer and Büchl-Zimmermann, 2015) and mounted on microscope slides. The ethanol-fixed liver sample was embedded in Paraplast (Vogel), cut into 3- to 4- $\mu$ m sections using a sliding microtome, and stained with periodic acid-Schiff reaction (PAS) as described by Hotchkiss (1948), as well as an amylase control stain (saliva test). The stained sections were stored in the dark at 5 to $7{ }^{\circ} \mathrm{C}$ to preserve stain intensity.

\section{Histopathologic Evaluation}

Liver samples were evaluated histologically for the following characteristics: fatty infiltration (severity of fat deposition and size of lipid droplets), glycogen storage (degree of glycogen storage and size of glycogen particles), and degenerative, inflammatory, fibrotic, and proliferative changes, which included liver cell degeneration, severity of hepatitis, total severity of fibrosis, severity of perisinusoidal fibrosis, and the number of bile ducts. The liver samples were evaluated "blindly" by a trained veterinarian using a light microscope (CETI-AC 22V IN, TOPIC-B, magnification $40 \times$ to $400 \times)$. Five liver lobules were randomly evaluated in each sample using the $10 \times, 20 \times$, and $40 \times$ objectives. Histologic changes were scored as focal (seen in one liver lobule only), multifocal (seen in 2 or more liver lobules), or diffuse (seen in 5 liver lobules). A standardized assessment key was used to evaluate individual histologic changes (Tables 1 and 2).

The severity of fatty infiltration of the liver samples was determined using the SIII-stained sections, and a modified scoring system described by Mertens (1992) to grade each sample. In contrast to the system described by Mertens (1992), classification of cellular fat infiltration was reduced from 6 to 4 classes and the scoring modified accordingly. In each of the liver lobule zones, which included the centrilobular, intermediate, and peripheral or periportal zones (Rappaport et al., 1954; Jungermann and Katz, 1989), size of lipid droplets was scored as follows: no lipid droplets seen (0), small droplets (1), medium-sized droplets (2), and large droplets (3), and the severity of lipid infiltration of hepatocytes was scored as none (0), mild (1), moderate (2), and severe (3). For each of the 3 zones, the total number of points was multiplied and the result added $[\Sigma$ (size of lipid droplets $\times$ severity of lipid infiltration 
Table 1. Applied histologic interpretation key for lesion types in liver tissue samples

\begin{tabular}{lll}
\hline Criterion & Degree & Definition \\
\hline Size of lipid droplets & No droplets & No droplets seen in section \\
& Small droplets & Droplets (red to orange) smaller than nucleus of hepatocytes \\
& Medium-sized droplets & $\begin{array}{l}\text { Droplets similar in size to nucleus of hepatocytes } \\
\text { Droplets larger than nucleus of hepatocytes }\end{array}$ \\
Size of glycogen particles & No PAS-positive material ${ }^{1}$ & No PAS-positive material \\
(according to Mertens, 1992) & Dust-like & Dust-like magenta to light violet colored glycogen particles \\
& Dust-like to granular & Dust-like and granular glycogen particles \\
& Granular & Predominantly granular glycogen particle size \\
& Granular to coarse & Granular and coarse glycogen particles \\
Hepatocyte degeneration & Coarse & Predominantly coarse glycogen particles \\
& No degeneration & No nuclear death apparent \\
& Degenerated cell nuclei & Nucleus (blue) displaced peripherally by fat vacuole; nuclear death \\
& & apparent \\
\hline
\end{tabular}

${ }^{1} \mathrm{PAS}=$ periodic acid-Schiff.

of hepatocytes) $)_{\mathrm{c}, \mathrm{i}, \mathrm{p}}$, where $\mathrm{c}=$ centrilobular zone, $\mathrm{i}=$ intermediate zone, and $\mathrm{pl}=$ peripheral or periportal zones]. The severity of lipid infiltration was calculated from the mean of the 5 liver lobules and scored as no lipid infiltration (0), mild (1-6 points), moderate (7-15 points), or severe (16-27 points; Figure 1). The size of lipid droplets was compared with the size of the hepatocyte nuclei in SIII-stained sections. The predominant size of the lipid droplets was used for analysis.

The degree of glycogen storage and its distribution within liver lobules were determined in PAS-reaction tissue sections (Figure 2). Furthermore, in contrast to the degree of glycogen storage, the predominant size of glycogen particles, according to the terminology used by Mertens (1992) rather than its percentage or distribution, was evaluated in PAS-reaction tissue sections (Figure 3).

The structure of hepatocyte nuclei was evaluated in HE-stained sections to determine the presence of liver cell degeneration. When regressive nuclear changes were seen in only a few hepatocytes, the sample was considered to have no degeneration. However, when similar nuclear changes were seen in multiple fields of view, hepatic degenerative changes were considered to be present.

Inflammatory cell infiltration (severity of hepatitis) was determined in HE-stained sections by evaluating the entire tissue section for the number of lymphocytes, plasma cells, neutrophils, and macrophages in inflammatory foci. The largest number of inflammatory cells in a given focus was used for analysis.

The PSR-stained sections were used to evaluate collagen deposits and to determine the overall severity of fibrosis. This included the presence of collagen deposits in the perisinusoidal space (space of Disse), as well as around the central vein or portal fields.

The severity of perisinusoidal fibrosis was also determined using PSR-stained sections. Perisinusoidal

Table 2. Applied histologic interpretation key for the severity of lesions in liver tissue samples

\begin{tabular}{|c|c|c|c|c|c|}
\hline Degree & $\begin{array}{l}\text { Hepatocyte } \\
\text { vacuolation }\end{array}$ & Glycogen & Hepatitis & $\begin{array}{l}\text { Overall } \\
\text { fibrosis }\end{array}$ & $\begin{array}{l}\text { Perisinusoidal } \\
\text { fibrosis }\end{array}$ \\
\hline No lesion & $\begin{array}{l}\text { No vacuoles (red to } \\
\text { orange) }\end{array}$ & $\begin{array}{l}\text { No PAS-positive } \\
\text { material }^{\text {1 }}\end{array}$ & $\begin{array}{l}\text { Fewer than } 10 \\
\text { inflammatory cells }\end{array}$ & $\begin{array}{l}\text { No fibrosis, no red- } \\
\text { staining material }\end{array}$ & $\begin{array}{l}\text { No red-staining material } \\
\text { in perisinusoidal area }\end{array}$ \\
\hline Moderate & $25 \%$ up to $50 \%^{3}$ & Granular, up to $50 \%^{4}$ & $\begin{array}{l}31-60 \text { inflammatory } \\
\text { cells }^{2}\end{array}$ & $\begin{array}{l}\text { Connective tissue } \\
\text { proportion up to } \\
50 \%^{4}\end{array}$ & $\begin{array}{l}\text { Distinct with } 10 \times \\
\text { objective, light to dark } \\
\text { red, very delicate to } \\
\text { several thicker strands, } \\
\text { partially diffuse }\end{array}$ \\
\hline Severe & More than $50 \%^{3}$ & $\begin{array}{l}\text { Granular to coarse } \\
\text { or coarse, more than } \\
50 \%^{4}\end{array}$ & $\begin{array}{l}\text { More than } 60 \\
\text { inflammatory cells }\end{array}$ & $\begin{array}{l}\text { Connective tissue } \\
\text { proportion more than } \\
50 \%^{4}\end{array}$ & $\begin{array}{l}\text { Massive, distinct, thick } \\
\text { strands, diffuse }\end{array}$ \\
\hline
\end{tabular}

\footnotetext{
${ }^{1} \mathrm{PAS}=$ periodic acid-Schiff.

${ }^{2}$ Accumulated in foci.

${ }^{3}$ Relative to the parenchymal area of the zone under investigation (centrilobular, intermediate, peripheral or periportal).

${ }^{4}$ Relative to the parenchymal area of the entire section.
} 
fibrosis was part of the overall fibrosis but focused on collagen deposits in the space of Disse (Figure 4). The mean number of bile ducts was determined on PSRstained sections. The number of bile ducts was counted in 5 portal fields and the mean calculated.

\section{Data and Statistical Analysis}

Histopathologic Scores. For analysis of the ordinal variable histopathologic score with repeated measurements within cows, the cumulative logit (random effect) model based on the threshold concept was used (McCulloch and Searle, 2001). Let $Y_{i j k l m}$ be the ordinal response (with $\mathrm{r}$ categories) of animal $m$ in treatment group $i$, sampling day $j$, metabotype $k$, and lactation class $l$. Further, let $Z_{i j k l m}$ be the underlying continuous latent variable and $\theta_{n}$ cutpoints (thresholds with $\mathrm{n}=$ $1, \ldots, r-1)$. Then, at given animal effect, the cumulative logit random effect model is given by:

$$
\operatorname{logit}\left[P\left(Y_{i j k l m} \leq n\right)\right]=\operatorname{logit}\left[P\left(Z_{i j k l m} \leq \theta_{n}\right)\right]=\theta_{n}-\eta_{i j k l m},
$$

with $\eta_{i j k l m}=\mu+G_{i}+T_{j}+$ metabotype $_{k}+L C_{l}+b_{1} \times$ $x_{i j k l m}+a_{i k l m}$, where $\eta_{i j k l m}$ is the linear predictor, $G_{i}=$ treatment group effect (fix; $i=1,2,3$ where $1=\mathrm{CON}$, $2=$ VER5, and $3=$ VER 10$), T_{j}=$ fixed sampling day effect $(j=1,2,3,4$, where $1=14 \mathrm{~d}$ AP, $2=7 \mathrm{~d} \mathrm{PP}, 3=$ 28 and $42 \mathrm{~d}$ PP), metabotype $_{k}=$ metabotype effect (fix; $k=1,2,3$, where $1=\mathrm{A}, 2=\mathrm{B}$, and $3=\mathrm{C}), L C_{l}=$ lactation class effect (fix; $l=1,2$, and 3 ), and $a_{i k l m}=$ random effect of animal $m$ in group $i$, metabotype $k$, and lactation class $l$, with $a_{i k l m} \sim N\left(0, \sigma_{a}^{2}\right)$. The difference between effective and planned sampling time points $\left(x_{i j k l m}\right)$ is accounted for by the linear regression coefficient $b_{1}$. A possible interaction of the factors metabotype and treatment was tested, but no significance was observed (data not shown). Because of the existing model complexity attributable to the main effects, we did not examine other interactions when considering the sample size.

For estimation of the model parameters, the maximum likelihood method implemented in PROC GLIMMIX of SAS 9.4 (SAS Institute) was used. The
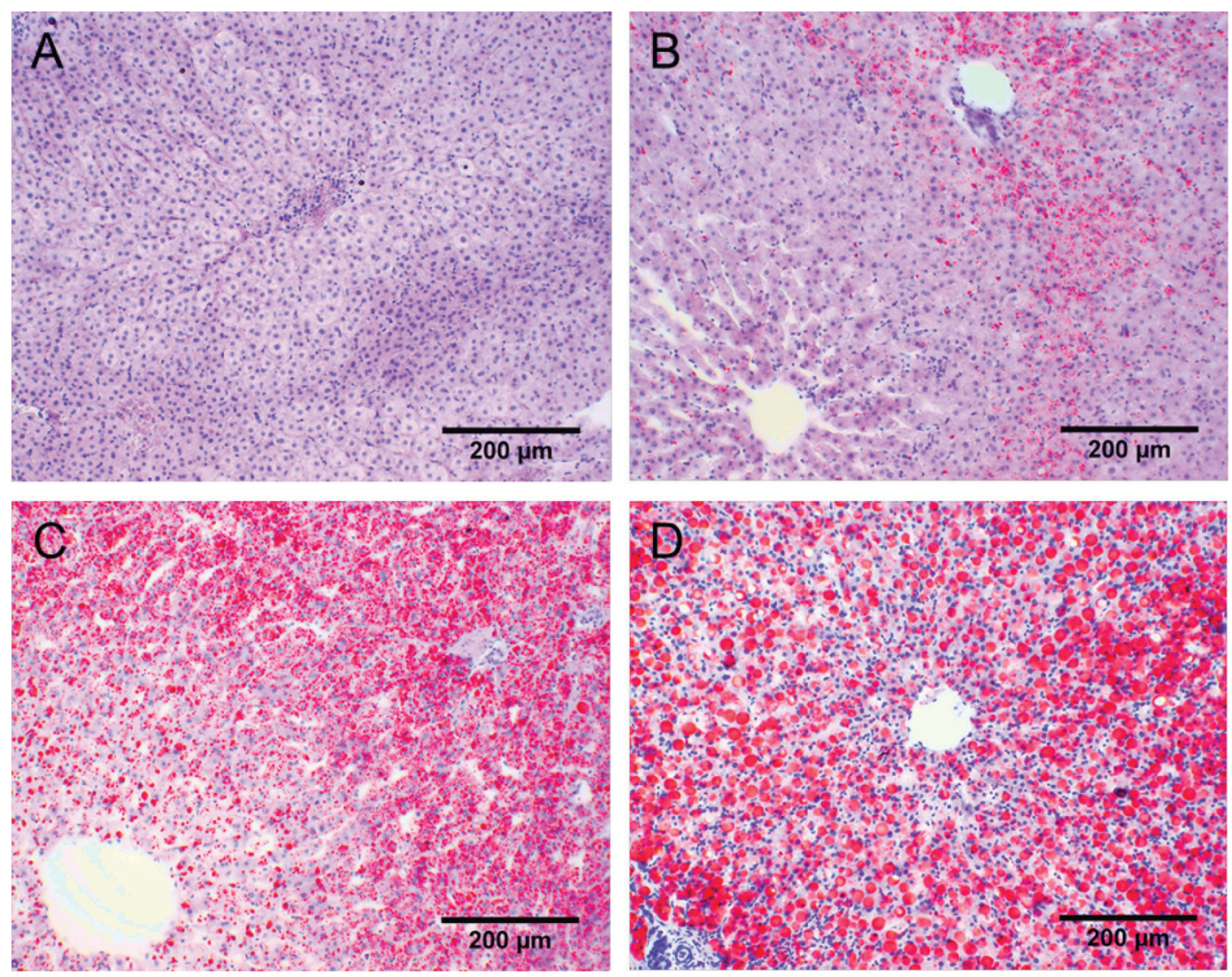

Figure 1. Degree of fatty infiltration of the liver in sections stained with Sudan III-hematoxylin: (A) no fatty infiltration (score 0 points); (B) mild fatty infiltration (score 3 points); (C) moderate fatty infiltration (score 13 points); and (D) severe fatty infiltration (score 27 points). 
implementation provides F-test (related to the effects in the linear predictor), cumulative probabilities, and odds ratio (OR). For statistical evaluation of the OR, simultaneous confidence intervals were provided using the Bonferroni correction.

Correlations. The reported correlation coefficients between the histopathologic scores were pooled Spearman correlations (PROC COR of SAS 9.4). The reported 2 evaluations levels were:

1) Evaluation over all data: Reported correlations are based on the pooled estimates within all combinations of sampling day $\times$ metabotype (these fixed effects were particularly important, see results F-test).

2) Evaluation per metabotype: Reported correlations were based on the pooled estimates within metabotype over all time periods.

We chose this form of estimation to avoid a bias of the correlation coefficient estimates due to the fixed effects.
Number of Bile Ducts. This trait was quantitative. Accordingly, we evaluated this trait by applying a linear mixed model (PROC MIXED of SAS 9.4). The effect structure was identical to the evaluation of the scores as described above. However, a log-transformation had to be done to ensure normal distribution of the residuals. The least squares means communicated for this feature were back-transformed to facilitate assessment of the results.

\section{RESULTS}

The variables fatty infiltration, glycogen storage, and liver cell degeneration changed during the study period and were also significantly influenced by the metabotype $(P \leq 0.05$; Table 3$)$. Metaphylactic treatment with butaphosphan and cyanocobalamin (VER5 and VER10) had no effect on histomorphologic variables, and lactation number only affected the incidence of perisinusoidal fibrosis $(P \leq 0.05)$. The difference between scheduled and effective sampling day of the liver
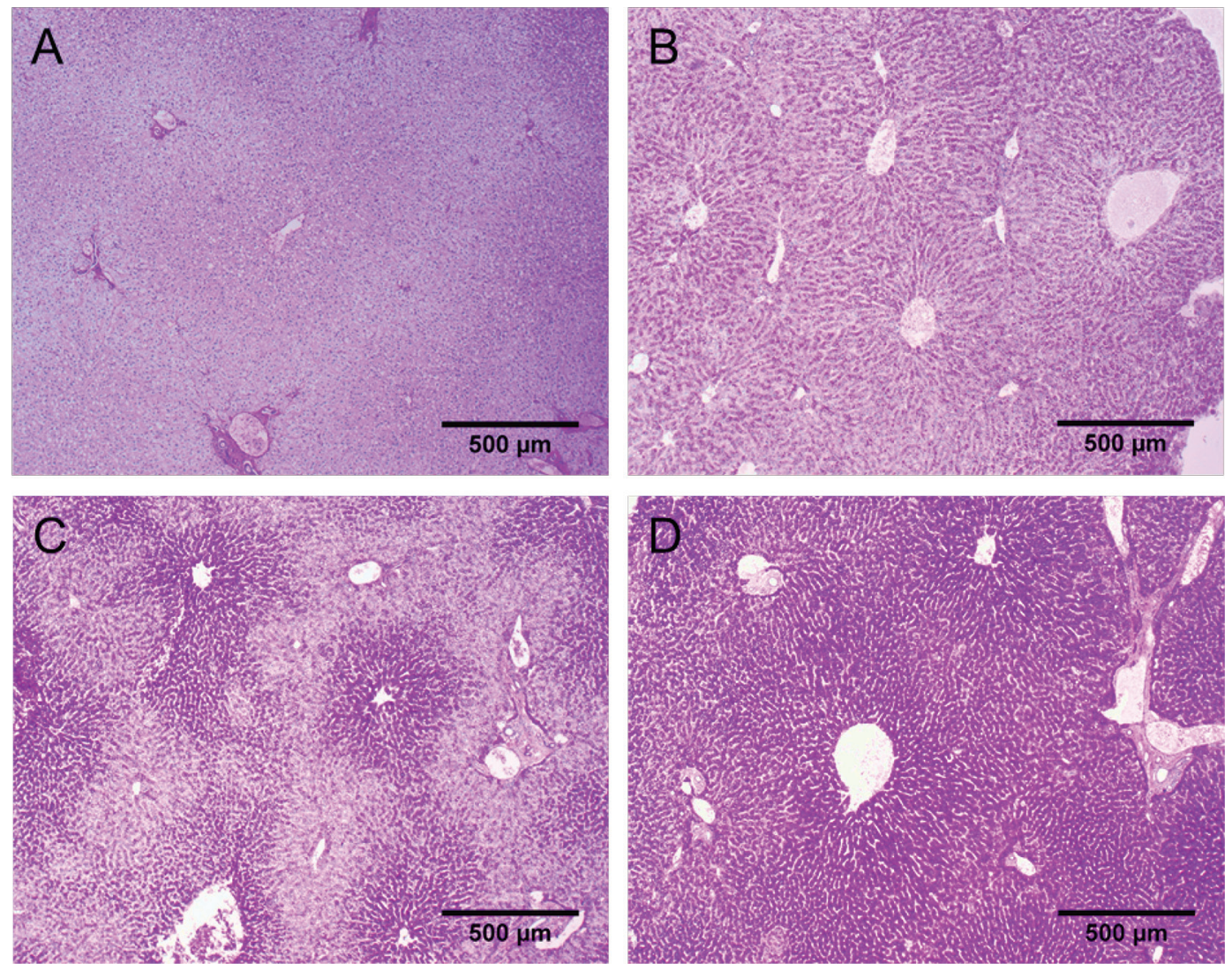

Figure 2. Degree of glycogen storage in sections with periodic acid-Schiff reaction: (A) no glycogen storage; (B) mild glycogen storage; (C) moderate glycogen storage; and (D) pronounced glycogen storage. 
biopsies had an effect on the variable fatty infiltration. The OR and $95 \%$ confidence intervals (CI) were calculated to describe differences among different levels of the effects sampling day, metabotype, and lactation number. The OR was considered to be significantly different from the value one when the $95 \%$ CI did not overlap with the value one. Only significant OR are shown in the text hereafter. The complete set of OR is depicted in Appendix Table A1.

\section{Fatty Infiltration}

The degree of fatty infiltration of the liver was mild to minimal before parturition (T1; Figure 5A) and increased after parturition; it was most severe at T2 (d 4-13 PP). The chance of lower fatty infiltration at T1 was 63.8 times the chance at $\mathrm{T} 2\left(\mathrm{OR}_{\mathrm{T} 1 / \mathrm{T} 2}\right)$. Fatty infiltration decreased with increasing DIM; the chance of lower fatty infiltration at T1 was 42.2 times the chance at $\mathrm{T} 3\left(\mathrm{OR}_{\mathrm{T} 1 / \mathrm{T} 3}\right)$ and 11.1 times the chance at $\mathrm{T} 4$ $\left(\mathrm{OR}_{\mathrm{T} 1 / \mathrm{T} 4}\right)$. This pattern of decreasing fatty infiltration was also apparent from $\mathrm{T} 2$ to $\mathrm{T} 4\left(\mathrm{OR}_{\mathrm{T} 2 / \mathrm{T} 4}=0.17\right)$ and from $\mathrm{T} 3$ to $\mathrm{T} 4\left(\mathrm{OR}_{\mathrm{T} 3 / \mathrm{T} 4}=0.26\right)$. The changes in the distribution of the size of lipid droplets in the liver were similar; lipid droplets were scant and mostly small at T1 (Figure 5B) but considerably larger at T2, T3, and $\mathrm{T} 4$, and lipid droplets were seen in almost all PP tissue sections. The chance of smaller droplets at $\mathrm{T} 1$ was 27.5 times the chance at $\mathrm{T} 2\left(\mathrm{OR}_{\mathrm{T} 1 / \mathrm{T} 2}\right), 36.6$ times the chance at $\mathrm{T} 3\left(\mathrm{OR}_{\mathrm{T} 1 / \mathrm{T} 3}\right)$, and 13.9 times the chance at $\mathrm{T} 4\left(\mathrm{OR}_{\mathrm{T} 1 / \mathrm{T} 4}\right)$. This pattern of decreasing lipid droplets size was furthermore apparent from $\mathrm{T} 3$ to $\mathrm{T} 4\left(\mathrm{OR}_{\mathrm{T} 3 / \mathrm{T} 4}\right.$ $=0.38)$.

The metabotypes had an effect $(P \leq 0.05)$ on fatty infiltration and lipid droplet size (Table 3 ). The chance of a lower degree of fatty infiltration in metabotype A ( $1 \%$ severe, $11 \%$ moderate, $61 \%$ mild, $27 \%$ no fatty infiltration) was 7.7 times the chance in metabotype $\mathrm{B}\left(\mathrm{OR}_{\mathrm{A} / \mathrm{B}} ; 6 \%\right.$ severe, $45 \%$ moderate, $44 \%$ mild, $5 \%$ no fatty infiltration). In contrast, the chance of lower fatty infiltration in metabotype $\mathrm{B}$ was only 0.38 times $\left(\mathrm{OR}_{\mathrm{B} / \mathrm{C}}\right)$ the chance observed in metabotype $\mathrm{C}(3 \%$
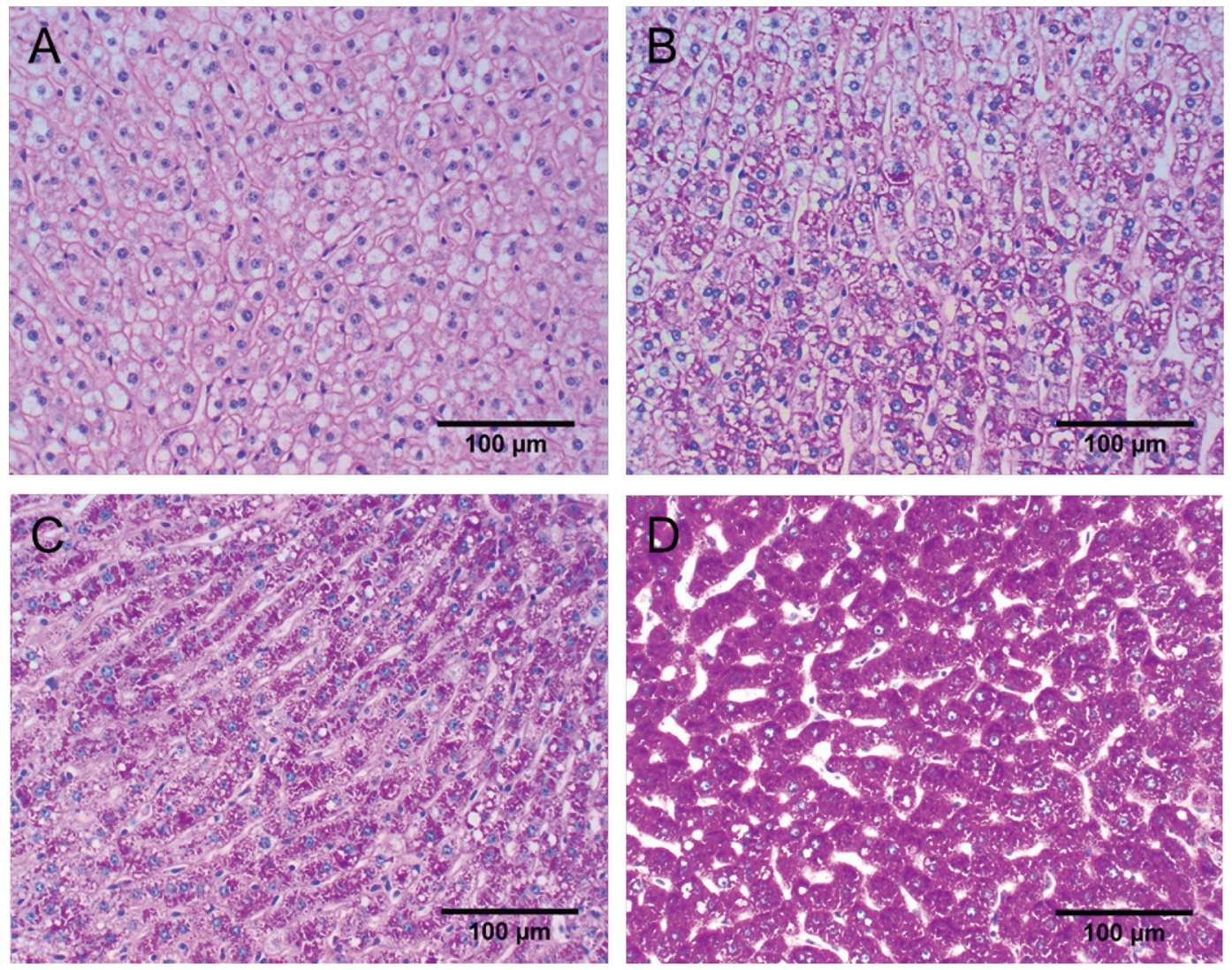

Figure 3. Size of glycogen particles in sections with periodic acid-Schiff reaction: (A) no glycogen; (B) dust-like glycogen particles; (C) dustlike to granular glycogen particles; and (D) coarse glycogen particles. 

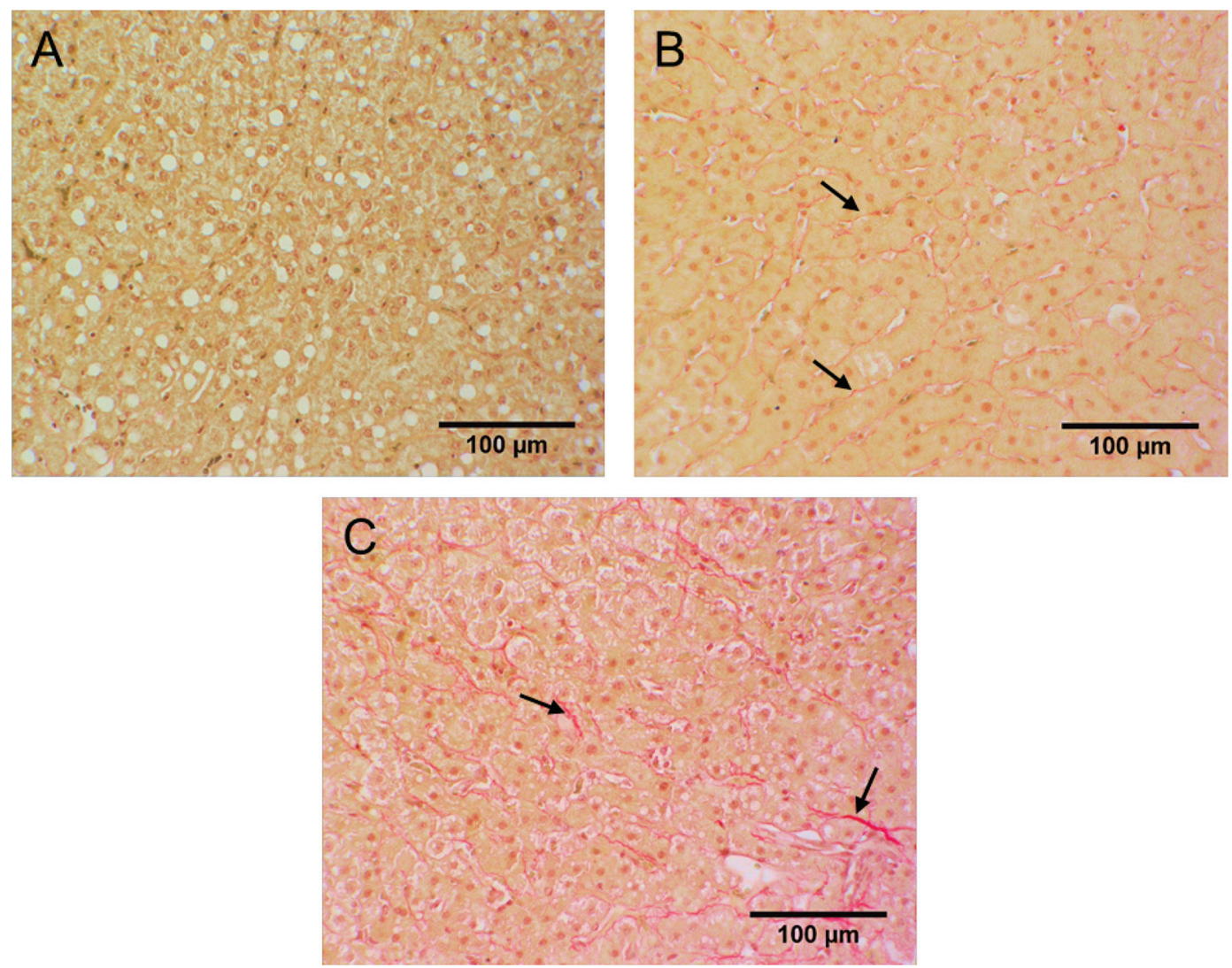

Figure 4. Degree of perisinusoidal fibrosis in sections stained with picrosirius red stain. Arrows point to perisinusoidal fibrosis: (A) no fibrosis; (B) mild fibrosis; and (C) moderate fibrosis. Severe fibrosis did not occur and is therefore not shown.

severe, $26 \%$ moderate, $60 \%$ mild, $11 \%$ no fatty infiltration). Additionally, the chance of a lower degree of fatty infiltration in metabotype $\mathrm{A}$ was $2.9\left(\mathrm{OR}_{\mathrm{A} / \mathrm{C}}\right)$ times the chance in metabotype $\mathrm{C}$. The chance of smaller lipid droplets sizes was $3.8\left(\mathrm{OR}_{\mathrm{A} / \mathrm{B}}\right)$ and $4.0\left(\mathrm{OR}_{\mathrm{A} / \mathrm{C}}\right)$ times the chance in metabotype A, compared with metabotype $\mathrm{B}$ and $\mathrm{C}$, respectively.

\section{Glycogen Storage}

The amount of glycogen stored in the liver was comparatively large at $\mathrm{T} 1$ (Figure 5C, D), reached a minimum at T2, and then increased toward T3 (Figure $5 \mathrm{C})$. The chance of a lower degree of glycogen storage at $\mathrm{T} 1$ was $0.02\left(\mathrm{OR}_{\mathrm{T} 1 / \mathrm{T} 2}\right)$ and 0.20 times $\left(\mathrm{OR}_{\mathrm{T} 1 / \mathrm{T} 3}\right)$, the

Table 3. $P$-values for the F-test for the fixed effects of the model [sampling day, metabotype, treatment group, lactation number, and regression for the correction of the difference between scheduled and effective sampling day of biopsy, Regr Corr Diff $\mathrm{T}$ ( $\left.\mathrm{b}_{1}\right)$ ] for the histologic assessment of liver biopsy samples from 80 German Holstein cows during the transition period

\begin{tabular}{|c|c|c|c|c|c|c|c|c|c|}
\hline \multirow[b]{2}{*}{ Fixed effect ${ }^{1}$} & \multicolumn{2}{|c|}{ Fat } & \multicolumn{2}{|c|}{ Glycogen } & \multicolumn{5}{|c|}{$\begin{array}{l}\text { Degenerative, inflammatory, fibrotic, } \\
\text { and proliferative lesion }{ }^{2}\end{array}$} \\
\hline & Degree & $\begin{array}{l}\text { Droplet } \\
\text { size }\end{array}$ & Degree & $\begin{array}{l}\text { Particle } \\
\text { size }\end{array}$ & $\begin{array}{c}\text { Hepat } \\
\text { deg }\end{array}$ & Нер & $\begin{array}{l}\text { Overall } \\
\text { fib }\end{array}$ & PSF & NBD \\
\hline Sampling day & $<0.001$ & $<0.001$ & 0.018 & 0.019 & 0.024 & 0.497 & 0.910 & 0.124 & 0.098 \\
\hline Metabotype & $<0.001$ & 0.006 & 0.012 & $<0.001$ & 0.007 & 0.642 & 0.411 & 0.041 & 0.257 \\
\hline Treatment group & 0.431 & 0.897 & 0.292 & 0.429 & 0.780 & 0.213 & 0.341 & 0.101 & 0.128 \\
\hline
\end{tabular}

${ }^{1}$ See model in Statistical Analysis section.

${ }^{2}$ Hepat deg $=$ hepatocyte degeneration; Hep = degree of hepatitis; Overall fib = overall fibrosis; PSF = degree of perisinusoidal fibrosis; NBD $=$ number of bile ducts.

${ }^{3} b_{1}=$ linear regression coefficient. 

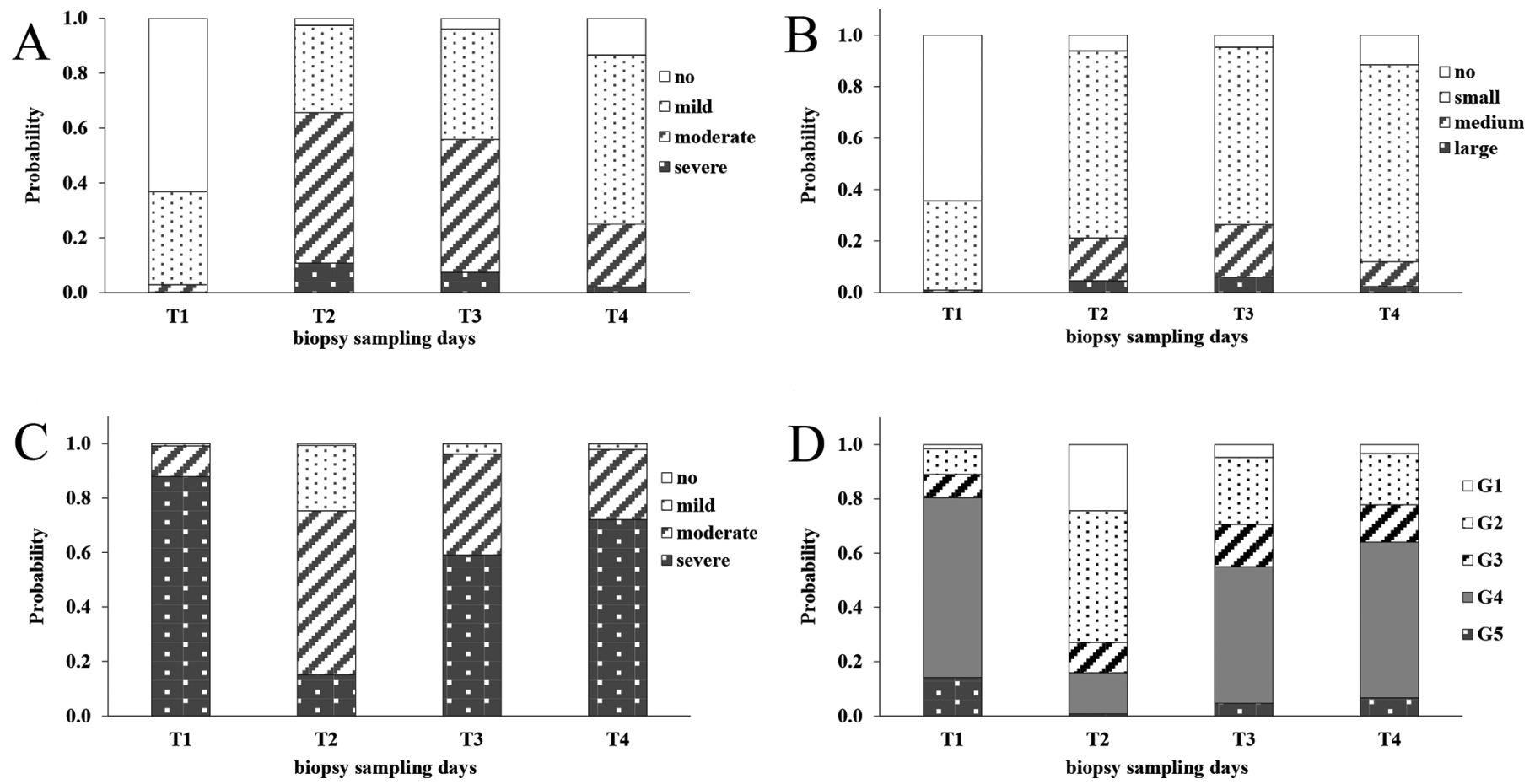

Figure 5. Probability estimation for the rating of the degree of fatty liver infiltration (A); size of fat droplets (B); degree of glycogen storage (C); and size of glycogen particles (D) in 80 German Holstein cows during the transition period. The columns show the probabilities at the sampling day of liver biopsy: T1 [12 d antepartum (AP)], T2 [7 d postpartum (PP)], T3 (28 d PP), and T4 (42 d PP). A and C, level of infiltration/storage: no, mild, moderate, and severe infiltration; B, size of fat droplets: no, small, medium, large droplets; D, particle size of deposits: G1, no or dust-like; G2, dust-like to granular; G3, granular; G4, granular to coarse; G5, coarse. For significance between the sampling days, see Table 3 and Appendix Table A1.

chance at $\mathrm{T} 2$ and $\mathrm{T} 3$, respectively (Appendix Table A1). This relation changed after T2; the chance of lower glycogen storage at $\mathrm{T} 2$ was $8.1\left(\mathrm{OR}_{\mathrm{T} 2 / \mathrm{T} 3}\right)$ and 14.6 times $\left(\mathrm{OR}_{\mathrm{T} 2 / \mathrm{T} 4}\right)$ the chance at $\mathrm{T} 3$ and $\mathrm{T} 4$, respectively.

With respect to the size of glycogen particles, the classes "no glycogen" and "dust-like" were pooled because of their low frequencies and because it facilitated presentation of the results (Figure 5D). The structure of the glycogen deposits was mostly larger glycogen particle size at $\mathrm{T} 1$, which had decreased to a minimum at $\mathrm{T} 2$, after which time the particle size increased again at $\mathrm{T} 3$. The chance of smaller glycogen particles at $\mathrm{T} 1$ was $0.05\left(\mathrm{OR}_{\mathrm{T} 1 / \mathrm{T} 2}\right)$ and 0.30 times $\left(\mathrm{OR}_{\mathrm{T} 1 / \mathrm{T} 3}\right)$ the chance at $\mathrm{T} 2$ and $\mathrm{T} 3$, respectively (Appendix Table A1). Glycogen particle size increased with increasing DIM; the chance of smaller glycogen particles deposits at T2 was $6.5\left(\mathrm{OR}_{\mathrm{T} 2 / \mathrm{T} 3}\right)$ and 9.4 times $\left(\mathrm{OR}_{\mathrm{T} 2 / \mathrm{T} 4}\right)$ the chance at $\mathrm{T} 3$ and $\mathrm{T} 4$, respectively.

The metabotype also had an effect on the degree of glycogen storage and the size of glycogen particle deposits. The chance of lower glycogen storage in metabotype A ( $77 \%$ severe, $21 \%$ moderate, $2 \%$ mild) was 0.29 times the chance in metabotype B (49\% severe, $45 \%$ moderate, $6 \%$ mild, $\mathrm{OR}_{\mathrm{A} / \mathrm{B}}$ ) and 0.31 times the chance in metabotype $\mathrm{C}$ ( $51 \%$ severe, $44 \%$ moderate, $5 \%$ mild, $\mathrm{OR}_{\mathrm{A} / \mathrm{C}}$ : Appendix Table A1). Similarly, the chance for smaller glycogen particles was $0.25\left(\mathrm{OR}_{\mathrm{A} / \mathrm{B}}\right)$ and 0.19 $\left(\mathrm{OR}_{\mathrm{A} / \mathrm{C}}\right)$ times the chance observed in metabotype $\mathrm{B}$ and $\mathrm{C}$, respectively.

\section{Degenerative, Inflammatory, Fibrotic, and Proliferative Changes}

The degree of liver cell degeneration was the only variable that was affected by sampling day $(P \leq 0.05$; Table 3). Regressive nuclear changes in hepatocytes were rare (1\%) at T1 but occurred in 24, 26, and $13 \%$ of hepatocytes, respectively, at T2, T3, and T4. The chance of normal hepatocyte nuclei at $\mathrm{T} 1$ was 28.0 $\left(\mathrm{OR}_{\mathrm{T} 1 / \mathrm{T} 2}\right), 31.1\left(\mathrm{OR}_{\mathrm{T} 1 / \mathrm{T} 3}\right)$, and 13.5 times $\left(\mathrm{OR}_{\mathrm{T} 1 / \mathrm{T} 4}\right)$ the chance at T2, T3, and T4, respectively (Appendix Table A1). With respect to the metabotypes, the chance of normal hepatocyte nuclei in metabotype A (5\% degenerative) was 4.43 times $\left(\mathrm{OR}_{\mathrm{A} / \mathrm{B}}\right)$ the chance in $\mathrm{B}(19 \%$ degenerative). Both metabotype $\mathrm{A}$ and $\mathrm{B}$ did not differ from metabotype $\mathrm{C}$ (11\% degenerative).

Metabotypes also affected the degree of perisinusoidal fibrosis. The chance of low-grade perisinusoidal 
fibrosis in metabotype A $(6 \%$ moderate, $45 \%$ mild, $49 \%$ absent) was 3.7 times the chance in metabotype B (18\% moderate, $61 \%$ mild, $21 \%$ absent; $\mathrm{OR}_{\mathrm{A} / \mathrm{B}} ; \mathrm{Ap}-$ pendix Table A1). Both metabotypes A and B did not differ from $\mathrm{C}$ (16\% moderate, $61 \%$ mild, $23 \%$ absent).

Degree of perisinusoidal fibrosis was the only variable affected $(P \leq 0.05)$ by lactation number; this lesion was more common in cows with lactation numbers 5 or greater (L3) than in younger cows. The chance of less severe perisinusoidal fibrosis in cows of L1 and L2 were $4.2\left(\mathrm{OR}_{\mathrm{L} 1 / \mathrm{L} 3}\right)$ and 4.4 times $\left(\mathrm{OR}_{\mathrm{L} 2 / \mathrm{L} 3}\right)$ the chance in cows of L3 (Appendix Table A1, Figure 6).

For the number of bile ducts in hepatic tissue, there was a trend for differences among sampling days (Ftest, $P=0.085$; Table 3 ); the largest difference occurred between T2 and T4 (Tukey-test, $P=0.11$ ). The numbers for T1, T2, T3, and T4 obtained after backtransformation were $1.76 \pm 0.05(\mathrm{LSM} \pm \mathrm{SE}), 1.77 \pm$ $0.04,1.80 \pm 0.05$, and $1.92 \pm 0.06$, respectively.

To assess the level of hepatitis, the severity of lymphocytic infiltration of the liver tissue was determined. Among the 4 biopsy time points, severe infiltration was seen in 10 to $15 \%$, moderate infiltration in 19 to $25 \%$, mild infiltration in 50 to $55 \%$, and no infiltration in 11 to $16 \%$ of cows. Not all specimens had inflammatory cell infiltration but periportal lymphocytic infiltration was most common and neutrophils and macrophages were rare. The level of hepatitis was also assessed based on the overall degree of fibrosis. Among the sampling days, the overall degree of fibrosis was moderate in less than $1 \%$ and mild in 44 to $64 \%$ of cows, and 36 to $56 \%$ of cows had no fibrosis. Severe fibrosis was not seen. The degrees of cellular infiltration and fibrosis were not affected by any of the effects studied (Table 3 ).

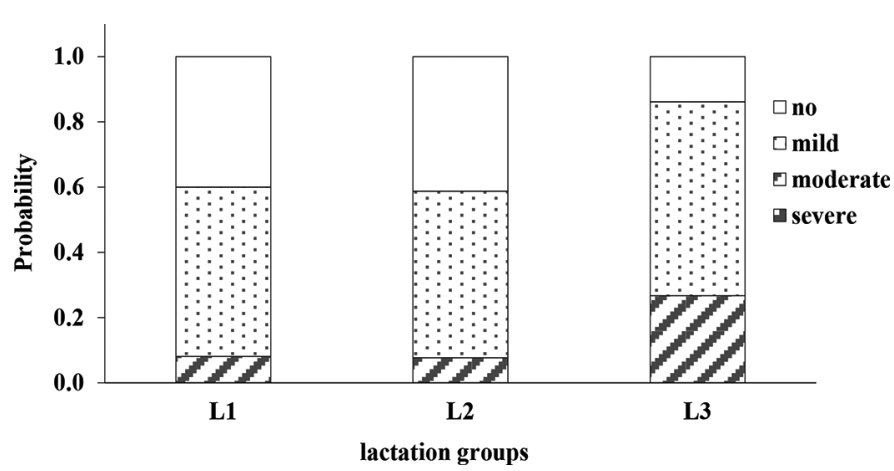

Figure 6. Probability estimation for the rating of the degree of perisinusoidal fibrosis in 80 German Holstein cows during the transition period. The columns show the probabilities for cows in different lactation groups at the sampling day of liver biopsy: second lactation (L1); third and fourth lactations (L2); fifth lactation and higher (L3). Degree of fibrosis: no, mild, moderate, and severe fibrosis. For significance between the sampling days, see Table 3 and Appendix Table A1.

\section{Correlations Among Variables}

There were several correlations $(P \leq 0.05)$ between the histologic variables (Appendix Table A2); however, the estimates varied depending on the metabotypes. The severity of fatty infiltration and size of lipid droplets were positively correlated $(P \leq 0.05)$ with large correlation coefficients. The same was true for the relationship between degree and particle size of glycogen deposits (Appendix Table A2).

There was a negative correlation $(P \leq 0.05)$ between the degree of glycogen storage and severity of fatty infiltration in metabotype $\mathrm{B}$ and $\mathrm{C}$, between degree of glycogen deposits and size of lipid droplets in metabotype $\mathrm{C}$, and between the size of glycogen particles and severity of fatty infiltration in metabotype B and C (Appendix Table A2).

Fatty infiltration was positively correlated $(P \leq 0.05)$ with hepatocyte degeneration in all metabotypes. Hepatocyte degeneration was also negatively correlated $(P$ $\leq 0.05$ ) with the degree of glycogen and size of glycogen particles; the correlations were strongest for the degree of deposits in metabotype B and C, and strongest for the size of glycogen particles in metabotype B. The overall degree of fibrosis was positively correlated with lipid droplet size in metabotype A and negatively correlated with the size of glycogen particles in metabotype C.

The overall degree of fibrosis was positively correlated with the degree of hepatitis and with the degree of perisinusoidal fibrosis in all metabotypes, whereas the degree of hepatitis was positively correlated $(P \leq$ $0.05)$ with hepatocyte degeneration only in metabotype B. In metabotype A the degree of perisinusoidal fibrosis was positively correlated $(P \leq 0.05)$ with the degree of hepatitis, whereas the overall degree of fibrosis was positively correlated with hepatocyte degeneration. There were positive correlations $(P \leq 0.05)$ between the number of bile ducts and several variables that were limited to certain metabotypes including the degree of fatty infiltration (metabotype A and B), lipid droplet size (metabotype A), degree of hepatitis (metabotype A), and overall degree of fibrosis (metabotype A and B). The degree of glycogen deposits was negatively correlated $(P \leq 0.05)$ with the overall degree of fibrosis in metabotype B.

\section{DISCUSSION}

\section{Usefulness of the Experimental Design for the Histologic Assessment}

The biopsy protocol used in our study for the assessment of histomorphologic changes in liver tissue during 
the transition period of dairy cows was similar to that used by others (Rukkwamsuk et al., 1999; Tharwat et al., 2012; Gohlke et al., 2013). Strict adherence to the experimental protocol was difficult in this commercial dairy herd for a variety of reasons but temporal deviations from the protocol were taken into account in the statistical analysis. We feel that our experimental protocol was sound because the histomorphologic findings largely reflected the metabolic changes observed during the transition period (see discussion section below).

The biopsy technique (Gohlke et al., 2013) provided tissue samples of adequate size. Liver biopsy specimens are representative of the whole liver regarding lipid content, fatty acid composition (Gaál and Husvéth, 1983; Gerspach et al., 2017), and glycogen concentration (Duplessis et al., 2020) in dairy cows. We did not see progressive liver fibrosis and therefore ruled out an adverse effect of repeated biopsy sample collection. In contrast, progressive fibrosis was seen in human medicine after repeat liver biopsy was performed for several years (Okanoue et al., 2005). In dairy cows, repeated liver biopsies do not seem to have an effect on the acute-phase proteins haptoglobin, serum amyloid A, fibrinogen, and IL-6, which have high sensitivity, or on body temperature, DMI, milk yield, and total white blood cell count (Vels et al., 2009; Jawor et al., 2016).

Fixation and preservation of tissue samples in formalin and alcohol, as well as storage at room temperature, provided high-quality and artifact-free histologic sections. Different stains and histochemical reactions allowed good differentiation of histologic and histochemical characteristics of the tissue. Staining with HE provided a good overview and differentiation of inflammatory cells but did not allow distinction between hydropic degeneration of hepatocytes, hepatocellular glycogen deposits, and small fat droplets (Levene et al., 2012); PAS reactions and SIII stains are required to stain glycogen and fat, respectively. The PAS reaction must be combined with diastase to allow for the differentiation of easily digestible carbohydrates (glycogen) and other PAS-positive substances such as glycolipids or neutral mucopolysaccharides (Riedelsheimer and Büchl-Zimmermann, 2015). We were able to identify an increase in collagen and elastic fibers in the PSRstained sections. Electron microscopic and immunohistochemical examinations would offer additional information about nuclear changes including nuclear hyperchromasia and karyopyknosis, changes in cell organelles (mitrochondria and endoplasmic reticulum), and the detection of other substances such as specific collagen fiber types (Collins and Reid, 1980; Konomi et al., 1981; Johannsen et al., 1993). The biochemical analysis of substances such as total lipids (TL), triacylglycerols, and glycogen would also be useful.

The interpretation key we chose was based on previous studies (Mertens, 1992; Rehage et al., 1996; Haudum, 2009) and was useful for the histologic and histochemical assessment of liver changes in dairy cows. Our findings relating to fatty infiltration of the liver (Reid, 1980; Gerloff et al., 1986; Jorritsma et al., 2001) and glycogen deposits (Rukkwamsuk et al., 1999; Weber et al., 2013; McCarthy et al., 2015) were in good agreement with previous studies. The characterization of the size of glycogen particles (Mertens, 1992; Figure 3) allowed a more detailed description of the structural processes during glycogen storage and metabolism than quantitative descriptions alone. Until now, there have been no studies on the dynamics of inflammatory, degenerative, fibrotic, and proliferative hepatic lesions in dairy cows during the transition period. Finally, it should be remembered that the use of any interpretation key is subjective and that its validity depends on the experience of the investigator; in the present study, the histologic specimens were assessed and classified by a closely supervised postgraduate veterinarian. Overall, we feel that the experimental design of the present study was suitable for the assessment of histopathologic liver changes in dairy cows during the transition period.

\section{Fat Accumulation in the Liver as a Reflection of a Negative Energy Balance}

We observed fat deposits in the liver of cows as early as 2 wk AP. This was most likely due to a reduction in DMI, which starts before parturition and causes an increase in free fatty acids (FFA; Bertics et al., 1992; Rukkwamsuk et al., 1999; Gross et al., 2013). Fatty infiltration of the liver reached a maximum at $\mathrm{T} 2$, which corresponded with the time of maximum mobilization of body fat. At $7 \mathrm{~d}$ (4-13 d; T2) PP, $66 \%$ of the cows had moderate to severe fatty infiltration, which was higher than frequencies reported earlier (Reid, 1980; Gerloff et al., 1986; Jorritsma et al., 2001). Even though fatty liver has been reported to increase the morbidity and mortality rate of production diseases (Breukink and Wensing, 1997) with a mortality rate of $25 \%$ for so-called fat cows (Morrow et al., 1979), all cows of the present study survived the transition period. Our findings strongly suggest that hepatic lipidosis of dairy cows is reversible (Johannsen et al., 1988; Rukkwamsuk et al., 1999; Fiore et al., 2017) and that fat deposits in the liver may disappear later in lactation. Thus, the histologic findings of the liver reflect the normal course of a negative energy balance (NEB) in dairy cows, 
which was also reflected in our clinical chemistry data (illustrated in Part I; Schären et al., 2021b).

\section{Negative Correlation Between Fat and Glycogen Storage}

The first biopsy sample collected PP showed a massive increase in fatty infiltration of the liver accompanied by a decrease in glycogen content. This was evidenced histologically by an increase in large lipid droplets and a decrease in the particle size of glycogen. This means that the dynamics of fat and glycogen metabolism contrasted one another. Our findings of a negative correlation between fat and glycogen metabolism confirmed earlier studies, which were based on only one or 2 biopsy sampling times (West, 1990; Mertens, 1992; Gerspach et al., 2017) and therefore unable to document histologic features throughout the transition period. Abatement of the NEB over time caused a decrease in fat content and a recovery of the glycogen deposits in the liver parenchyma by the end of the study period at d $42(37-50 \mathrm{~d}$; T4).

\section{The Effect of Metabotypes on Energy Metabolism}

A pronounced difference in energy metabolism was observed between the metabotypes. An overview of the effects on production and clinical traits, and clinical chemistry is given in Part I (Schären et al., 2021b). In metabotype B pre-fresh cows had a higher BCS than metabotype $\mathrm{A}$ and $\mathrm{C}$, decreasing by one score from 3.11 at $\mathrm{T} 1$ to 2.19 at $14 \mathrm{~d} \mathrm{PP}$, which was consistent with a much more pronounced fat mobilization than in the cows of the other metabotypes. Parallelly, cows of metabotype B had higher milk fat content and higher blood concentrations of bilirubin, FFA and triacylglycerols, higher activities of gamma-glutamyl transferase, and a higher change to be diseased during the first 30 DIM compared with the cows of the other metabotypes. These clinical variables are consistent with the observed increased fatty infiltration of the liver in metabotype B.

\section{Findings Suggestive of Steatohepatitis and Potential Fibrous Liver Changes in Dairy Cows}

When inflammatory cells were present in liver samples, the main finding in the transition period was lymphocytic, periportal hepatitis; $39 \%$ of the cows had moderate to severe hepatitis. In all likelihood, this was nonspecific, reactive hepatitis characterized by focal or diffuse lymphohistiocytic infiltration of the portal area of the liver (Neumann and Danner, 1998; Rothuizen and van den Ingh, 1998; Cullen and Stalker, 2016).
This was in agreement with previous reports of inflammatory lesions in the liver and in body fat of dairy cows in the first few weeks of lactation (Fürll, 1989; Mertens, 1992; Kalaitzakis et al., 2007). The insufficient energy availability, for instance during the transition period, impairs the ability of dairy cows to mount a sufficient immune response (McCarthy et al., 2016). In the context of fat mobilization, BHB (Suriyasathaporn et al., 2000), and FFA (Lacetera et al., 2004) impair the immune response or lead to a higher incidence of infections, which can predispose to inflammatory diseases, such as metritis, mastitis, or hepatitis, as observed in our study. Overall, inflammatory signs were not correlated with fatty infiltration of the liver, which was in agreement with a previous study (Bradford et al., 2015); however, the occurrence of moderate to severe lymphocytic infiltration of the liver in almost $40 \%$ of the cows appears to justify the diagnosis of steatohepatitis.

In contrast, hepatocyte degeneration was highly correlated with fatty infiltration of the liver. It is believed that previously formed small lipid droplets coalesce (Mertens, 1992; Walther and Farese, 2012) to form large droplets, which displace and suppress the cell nucleus, possibly giving rise to a mechanical form of nuclear degeneration (Johannsen et al., 1988, Fürll, 1989). The proportion of triacylglycerol of TL in liver tissue of German Holstein cows remains almost constant when the content of TL is $100 \mathrm{mg} / \mathrm{g}$ of fresh liver tissue or greater (Starke et al., 2010), and therefore, one can assume that severe hepatic lipidosis is characterized by the accumulation of other lipid fractions, such as cholesterol, cholesterol ester, and FFA in hepatocytes (Reid et al., 1977; Collins and Reid, 1980; Bobe et al., 2004). In human medicine, it has been shown that FFA have a toxic effect on hepatocytes and that fat vacuoles have a protective effect (Cusi, 2009; Garbarino and Sturley, 2009; Neuschwander-Tetri, 2010). Whether this also applies to cows with fatty infiltration of the liver is not known but is currently under investigation $[\mathrm{K}$. B. Theinert (Leipzig University, Germany), T. Snedec (Leipzig University, Germany), F. Pietsch (Leipzig University, Germany), S. Theile (Leipzig University, Germany), A.-S. Leonhardt (Leipzig University, Germany), J. Spilke (Martin-Luther University, Halle-Wittenberg, Germany), E. Bannert (Leipzig University, Germany), S. Pichelmann (University of Fribourg, Switzerland), H. Fuhrmann (Leipzig University, Germany), W. Baumgartner (University of Veterinary Medicine, Vienna, Austria), M. Schären (Leipzig University, Germany), and A. Starke (Leipzig University, Germany); unpublished data]. Fatty infiltration of the liver is a transient occurrence in dairy cows, and therefore, the 
potential for a lipotoxic effect remains when FFA are mobilized from triacylglycerol (Schaffer, 2003).

We did not observe a correlation between fatty infiltration and fibrosis of the liver, possibly because of differences in glycogen metabolism in people and ruminants. In human beings, glycogen is generated primarily in musculature in response to physical activity, whereas in ruminants, it occurs predominantly in the liver (Gardner et al., 2014). Of note, we were able to document glycogen deposits in the biopsy specimens throughout the transition period, and there were several negative trends in the relationships between glycogen deposits and degree of fibrosis of the liver (Appendix Table A2). This could be interpreted as a regenerative effect on the bovine liver with the potential to limit the adverse effect of fatty infiltration. Perisinusoidal fibrosis was more common in older cows than in younger cows. Perisinusoidal fibrosis is thought to have an adverse effect on liver function in humans (Schaffner et al., 1963) and the loss of microvilli and characteristic fenestrations in the space of Disse in animals. The sinusoids are transformed functionally and morphologically into capillaries (so-called capillarization of sinusoids), which is thought to impair the exchange of metabolically important substances between the hepatocytes and the blood plasma (Braet and Wisse, 2002; Cullen and Stalker, 2016). We were unable to determine whether perisinusoidal fibrosis had an adverse effect on liver function. We suspect that perisinusoidal fibrosis is the result of increased blood pressure because blood flow to the liver is increased in high-producing dairy cows (Sangsritavong et al., 2002), leading to increased pressure in the liver sinusoids. Milk yield increases with increasing lactation number to a maximum in the fifth lactation, and this could have had an effect on the degree of perisinusoidal fibrosis seen in our study.

The swelling of the liver parenchyma causes an increase in intrahepatic pressure resulting in compression of the liver sinusoids (Orrego et al., 1981). In human medicine, it is hypothesized that sinusoidal pressure increases because of tensile and shear forces accompanied by compression, which is caused by volume increase attributable to fat and inflammatory cell infiltration, ultimately stimulating fibrosis (Mueller, 2016). Reid and Collins (1980) reported an increased liver cell volume and compression of hepatic sinusoids caused by fat-laden liver cells in cows with fatty liver. Haudum et al. (2011) and Starke et al. (2011) described the adverse effects of the degree of hepatic lipidosis on the venous pulsatility index and blood flow velocity and thus on liver function in dairy cows. This observation was based on a reduction in elasticity of blood vessels, which occurred as a result of swelling of the liver parenchyma when the triacylglycerol content exceeded $150 \mathrm{mg} / \mathrm{g}$ fresh liver tissue.

Interestingly, there were trends toward the development of steatohepatitis and fibrotic changes in metabotype B animals, which suggests that inflammatory, degenerative, fibrotic, and proliferative reactions in the liver are possible during periods of inadequate feed quality. Number of bile ducts was correlated with degree of hepatic lipidosis, extent and size of glycogen particles, and overall degree of fibrosis, and there was a trend toward a correlation for perisinusoidal fibrosis. Furthermore, cows of metabotype B had more severe NEB and a higher morbidity rate. Possibly, the more pronounced NEB in metabotype B led to an increase in lipolysis and in turn to inflammatory dysregulation affected by FFA (Contreras et al., 2018). These observations are in all likelihood related to poor silage. Silage with elevated butyrate concentrations could increase BHB production accompanied by a decrease in feed intake (Stöber and Scholz, 1991). The first pass effect, which is the uptake of an absorbed substance by the liver before the substance reaches the systemic circulation, could also have played a role because it may have caused flooding of the liver with toxins and in turn, the development of inflammatory, degenerative, fibrotic, and proliferative liver lesions. Mycotoxins, for instance aflatoxins, are thought to favor the development of liver fibrosis, bile duct proliferation (Newberne and Butler, 1969; Lynch et al., 1971), and immunosuppression (Sultana and Hanif, 2009). More severe injury, or conditions that inhibit replication of mature cells, causes proliferation of bipotential progenitor cells (or oval cells), referred to as ductular reaction. These cells can mature into hepatocytes or bile duct epithelium (Sell, 1994; Cullen and Stalker, 2016). This could provide an alternative explanation for the proliferation of bile ducts seen in cows in metabotype B. Moreover, aflatoxins, fumonisin, and pyrrolizidine alkaloids are hepatotoxic and cancerogenic in cattle (Sultana and Hanif, 2009; Petzinger, 2011).

\section{CONCLUSIONS}

The liver biopsy technique, the histopathologic interpretation key, and the histologic stains used were suitable for addressing the goals of this study and for the histopathologic assessment of liver tissue from dairy cows. Electron microscopic and immunohistochemical examinations were not done but could increase the information regarding liver lesions in the transition period at the cellular level. The NEB in dairy cows during the transition period caused massive accumulation of fat in the liver accompanied by pronounced 
glycogen depletion. This negative correlation between fat and glycogen metabolism was reversible. The occurrence of numerous inflammatory cells in liver tissue and hepatocyte degeneration suggested a diagnosis of steatohepatitis in German Holstein cows. We observed a striking increase in perisinusoidal fibrosis in older cows, which could be a precursor of liver fibrosis. The histopathological features show a strong interrelation with the metabotypes identified in Part I (Schären et al., 2021b). Cows with little alterations in their liver metabolome across the transition period (metabotype B) exhibited an increased risk of fatty infiltration of the liver, lower glycogen storage and an interrelation with degenerative, inflammatory, fibrotic, and proliferative traits. These findings support the assumption of a bad grass silage quality as a causative factor.

\section{ACKNOWLEDGMENTS}

We thank the management and employees of Wirtschaftshof Sachsenland Standort Bräunsdorf for their help during the study and afterwards, the team at the Clinic for Ruminants and Swine and at the Institute of Veterinary Pathology for their help with the design and execution of the study. Furthermore, we thank Bayer Animal Health GmbH and ESAOTE Biomedica Deutschland $\mathrm{GmbH}$ for the financial support. The authors have not stated any conflicts of interest.

\section{REFERENCES}

Aschenbach, J. R., N. B. Kristensen, S. S. Donkin, H. M. Hammon, and G. B. Penner. 2010. Gluconeogenesis in dairy cows: The secret of making sweet milk from sour dough. IUBMB Life 62:869-877. https://doi.org/10.1002/iub.400.

Bergman, E. N. 1990. Energy contributions of volatile fatty acids from the gastrointestinal tract in various species. Physiol. Rev. 70:567590. https://doi.org/10.1152/physrev.1990.70.2.567.

Bertics, S. J., R. R. Grummer, C. Cadorniga-Valino, and E. E. Stoddard. 1992. Effect of prepartum dry matter intake on liver triglyceride concentration and early lactation. J. Dairy Sci. 75:1914-1922. https://doi.org/10.3168/jds.S0022-0302(92)77951-X.

Bobe, G., J. W. Young, and D. C. Beitz. 2004. Invited review: Pathology, etiology, prevention, and treatment of fatty liver in dairy cows. J. Dairy Sci. 87:3105-3124. https://doi.org/10.3168/jds .S0022-0302(04)73446-3.

Bradford, B. J., K. Yuan, J. K. Farney, L. K. Mamedova, and A. J. Carpenter. 2015. Invited review: Inflammation during the transition to lactation: new adventures with an old flame. J. Dairy Sci. 98:6631-6650. https://doi.org/10.3168/jds.2015-9683.

Braet, F., and E. Wisse. 2002. Structural and functional aspects of liver sinusoidal endothelial cell fenestrae: A review. Comp. Hepatol. 1:1. https://doi.org/10.1186/1476-5926-1-1.

Breukink, H. J., and T. Wensing. 1997. Pathophysiology of the liver in high yielding dairy cows and its consequences for health and production. Isr. J. Vet. Med. 52:66-72.

Collins, R. A., and I. M. Reid. 1980. A correlated biochemical and stereological study of periparturient fatty liver in the dairy cow. Res. Vet. Sci. 28:373-376. https://doi.org/10.1016/S0034 $-5288(18) 32725-5$.
Constantine, V. S. 1969. A combined tissue stain for the selective staining of collagen, elastic fibers and acidic carbohydrates. J. Invest. Dermatol. 52:353-356. https://doi.org/10.1038/jid.1969.60.

Contreras, G. A., C. Strieder-Barboza, and J. De Koster. 2018. Symposium review: Modulating adipose tissue lipolysis and remodeling to improve immune function during the transition period and early lactation of dairy cows. J. Dairy Sci. 101:2737-2752. https://doi .org/10.3168/jds.2017-13340.

Cullen, J. M., and M. J. Stalker. 2016. Liver and Biliary System. Pages 258-352 in Jubb, Kennedy, and Palmer's Pathology of Domestic Animals. M. G. Maxie, ed. 6th ed. Vol. 2. Elsevier Health Sciences.

Cusi, K. 2009. Role of insulin resistance and lipotoxicity in non-alcoholic steatohepatitis. Clin. Liver Dis. 13:545-563. https://doi.org/ 10.1016/j.cld.2009.07.009.

Duplessis, M., L. Blais, W. Poisson, and C. L. Girard. 2020. Extrapolation of hepatic glycogen concentration of the whole organ by performing a liver biopsy. J. Dairy Sci. 103:4858-4862. https://doi .org/10.3168/jds.2019-17905.

Edmonson, A. J., I. J. Lean, L. D. Weaver, T. Farver, and G. Webster. 1989. A body condition scoring chart for Holstein dairy cows. J. Dairy Sci. 72:68-78. https://doi.org/10.3168/jds.S0022 -0302(89)79081-0.

Elliot, J. M. 1976. The glucose economy of the lactating dairy cow. Pages 59-66 in Proc. Cornell Nutr. Conf. Feed Manuf., Ithaca, NY. Cornell University.

Fiore, E., G. Piccione, L. Perillo, A. Barberio, E. Manuali, M. Morgante, and M. Gianesella. 2017. Hepatic lipidosis in high-yielding dairy cows during the transition period: Haematochemical and histopathological findings. Anim. Prod. Sci. 57:74-80. https://doi .org/10.1071/AN15262.

Fürll, M. 1989. Vorkommen, Ätiologie, Pathogenese, Diagnostik und medikamentelle Beeinflussung von Leberschäden beim Rind, DVM Thesis, Veterinärmedizinische Fakultät, Universität Leipzig, Germany. [in German]

Gaál, T., and F. Husvéth. 1983. Comparison of the liver biopsy sample and the "whole liver" in respect of lipid content and fatty acid composition of lipids. Acta Vet. Hung. 31:51-56.

Garbarino, J., and S. L. Sturley. 2009. Saturated with fat: New perspectives on lipotoxicity. Curr. Opin. Clin. Nutr. Metab. Care 12:110-116. https://doi.org/10.1097/MCO.0b013e32832182ee.

Gardner, G. E., P. McGilchrist, and D. W. Pethick. 2014. Ruminant glycogen metabolism. Anim. Prod. Sci. 54:1575-1583. https://doi .org/10.1071/AN14434.

Gerloff, B. J., T. H. Herdt, and R. S. Emery. 1986. Relationship of hepatic lipidosis to health and performance in dairy cattle. J. Am. Vet. Med. Assoc. 188:845-850.

Gerspach, C., S. Imhasly, R. Klingler, M. Hilbe, S. Hartnack, and M. Ruetten. 2017. Variation in fat content between liver lobes and comparison with histopathological scores in dairy cows with fatty liver. BMC Vet. Res. 13:98. https://doi.org/10.1186/s12917-017 -1004-9.

Gohlke, A., C. J. Ingelmann, G. Nürnberg, J. M. Weitzel, H. M. Hammon, S. Görs, A. Starke, S. Wolffram, and C. C. Metges. 2013 Influence of 4-week intraduodenal supplementation of quercetin on performance, glucose metabolism, and mRNA abundance of genes related to glucose metabolism and antioxidative status in dairy cows. J. Dairy Sci. 96:6986-7000. https://doi.org/10.3168/ jds.2013-6852.

Gross, J. J., F. J. Schwarz, K. Eder, H. A. van Dorland, and R. M. Bruckmaier. 2013. Liver fat content and lipid metabolism in dairy cows during early lactation and during a mid-lactation feed restriction. J. Dairy Sci. 96:5008-5017. https://doi.org/10.3168/jds .2012-6245.

Grüninger, B. U. 1996. Zur Pathogenese von Angiopathien im Endometrium der Stute - Morphologisch-funktionelle Untersuchungen, DVM Thesis, Univ. Leipzig, Germany. [in German]

Haudum, A. 2009. Echotexturanalyse des Lebergewebes zur nicht-invasiven Bestimmung des Leberfettgehaltes bei Milchrindern, DVM Thesis, Tierärztliche Hochschule Hannover, Germany. [in German]

Haudum, A., A. Starke, M. Beyerbach, P. Wohlsein, and J. Rehage 2011. Ultrasonographic assessment of liver dimensions in dairy 
cows with different hepatic triacylglycerol content. J. Anim. Sci. 89:1392-1400. https://doi.org/10.2527/jas.2010-3287.

Herdt, T. H. 1988. Fuel homeostasis in the ruminant. Vet. Clin. North Am. Food Anim. Pract. 4:213-231. https://doi.org/10.1016/S0749 -0720(15)31045-8.

Hotchkiss, R. D. 1948. A microchemical reaction resulting in the staining of polysaccharide structure in fixed tissue preparations. Arch. Biochem. 16:131-141.

Jawor, P., A. Brzozowska, K. Słoniewski, Z. M. Kowalski, and T. Stefaniak. 2016. Acute phase response in the primiparous dairy cows after repeated percutaneous liver biopsy during the transition period. Pol. J. Vet. Sci. 19:393-399. https://doi.org/10.1515/pjvs $-2016-0049$.

Johannsen, U., S. Menger, R. Staufenbiel, and H. Kulkas. 1993. Untersuchungen zur Morphologie und Funktion der Leber von Hochleistungskühen 2 Wochen post partum. Dtsch. Tierarztl. Wochenschr. 100:177-181. [in German]

Johannsen, U., M. Schäfer, and A. Uhlig. 1988. Untersuchungen zur Leberfunktion der Milchkühe im peripartalen Zeitraum: 3. Mitteilung: Vorkommen und Dynamik von Lipideinlagerungen in der Leber. Arch. exper. Vet. Med. 42:118-134. [in German]

Jorritsma, R., H. Jorritsma, Y. H. Schukken, P. C. Bartlett, Th. Wensing, and G. H. Wentink. 2001. Prevalence and indicators of post partum fatty infiltration of the liver in nine commercial dairy herds in The Netherlands. Livest. Prod. Sci. 68:53-60. https://doi .org/10.1016/S0301-6226(00)00208-6.

Jungermann, K., and N. Katz. 1989. Functional specialization of different hepatocyte populations. Physiol. Rev. 69:708-764. https:// doi.org/10.1152/physrev.1989.69.3.708

Kabisch, J., K. Klose, and H. A. Schoon. 2019. Endometrial biopsies of old mares-What to expect?! Pferdeheilkunde 35:211-219. https: //doi.org/10.21836/PEM20190302.

Kalaitzakis, E., N. Roubies, N. Panousis, K. Pourliotis, E. Kaldrymidou, and H. Karatzias. 2007. Clinicopathologic evaluation of hepatic lipidosis in periparturient dairy cattle. J. Vet. Intern. Med. 21:835-845. https://doi.org/10.1111/j.1939-1676.2007.tb03029.x.

Konomi, H., J. Sano, and Y. Nagai. 1981. Immunohistochemical localization of types I, III and IV (basement membrane) collagens in the lymph node: Co-distribution of types I and III collagens in the reticular fibers. Biomed. Res. 2:536-545. https://doi.org/10.2220/ biomedres.2.536.

Lacetera, N., D. Scalia, O. Franci, U. Bernabucci, B. Ronchi, and A. Nardone. 2004. Effects of nonesterified fatty acids on lymphocyte function in dairy heifers. J. Dairy Sci. 87:1012-1014. https://doi .org/10.3168/jds.S0022-0302(04)73246-4.

Levene, A. P., H. K. Kudo, M. J. Armstrong, M. R. Thursz, W. M. Gedroyc, Q. M. Anstee, and R. D. Goldin. 2012. Quantifying hepatic steatosis-more than meets the eye. Histopathology 60:971-981. https://doi.org/10.1111/j.1365-2559.2012.04193.x.

Lynch, G. P., W. T. Shalkop, N. M. Jacoby, D. F. Smith, and R. W. Miller. 1971. Responses of dairy calves to oral doses of aflatoxin. J. Dairy Sci. 54:1688-1698. https://doi.org/10.3168/jds.S0022 -0302(71)86090-3.

Mayer, P. 1920. Zoomikrotechnik. Bornträger, Berlin. [in German]

McCarthy, M. M., M. S. Piepenbrink, and T. R. Overton. 2015. Associations between hepatic metabolism of propionate and palmitate in liver slices from transition dairy cows. J. Dairy Sci. 98:70157024. https://doi.org/10.3168/jds.2015-9695.

McCarthy, M. M., T. Yasui, M. J. B. Felippe, and T. R. Overton. 2016. Associations between the degree of early lactation inflammation and performance, metabolism, and immune function in dairy cows. J. Dairy Sci. 99:680-700. https://doi.org/10.3168/jds.2015-9694.

McCulloch, C. E., and S. R. Searle. 2001. Generalized, Linear, and Mixed Models - Wiley Series in Probability and Statistics. John Wiley and Sons Inc.

Mertens, M. 1992. Leberbiopsie beim Rind - Histologische und enzymatische Auswertung von Bioptaten aus Kühen mit Dislocatio abomasi sinistra, DVM Thesis, Hannover, Germany. [in German]

Morrow, D. A., D. Hillman, and A. W. Dade. 1979. Clinical investigation of dairy herd with the fat cow syndrome. J. Am. Vet. Med. Assoc. 174:161-167.
Mueller, S. 2016. Does pressure cause liver cirrhosis? The sinusoidal pressure hypothesis. World J. Gastroenterol. 22:10482-10501. https://doi.org/10.3748/wjg.v22.i48.10482.

Neumann, S., and W. Danner. 1998. Reactive hepatitis in dogs. Glob. Vet. 9:454-459. https://doi.org/10.5829/idosi.gv.2012.9.4.653.

Neuschwander-Tetri, B. A. 2010. Hepatic lipotoxicity and the pathogenesis of nonalcoholic steatohepatitis: The central role of nontriglyceride fatty acid metabolites. Hepatology 52:774-788. https:// doi.org/10.1002/hep.23719.

Newberne, P. M., and W. H. Butler. 1969. Acute and chronic effects of aflatoxin on the liver of domestic and laboratory animals a review. Cancer Res. 29:236-250.

Okanoue, T., A. Makiyama, M. Nakayama, Y. Sumida, H. Mitsuyoshi, T. Nakajima, K. Yasui, M. Minami, and Y. Itoh. 2005. A follow-up study to determine the value of liver biopsy and need for antiviral therapy for hepatitis $\mathrm{C}$ virus carriers with persistently normal serum aminotransferase. J. Hepatol. 43:599-605. https://doi.org/10 .1016/j.jhep.2005.04.008.

Orrego, H., L. M. Blendis, I. R. Crossley, A. Medline, A. Macdonald, S. Ritchie, and Y. Israel. 1981. Correlation of intrahepatic pressure with collagen in the Disse space and hepatomegaly in humans and in the rat. Gastroenterology 80:546-556. https://doi.org/10.1016/ 0016-5085(81)90018-4.

Petzinger, E. 2011. Pyrrolizidine alkaloids and seneciosis in farm animals. Part 2: Clinical signs, species-specific sensitivity, food residues, feed contamination, limit values. Tierarztl. Prax. Ausg. G Grosstiere Nutztiere 39:363-372.

Rappaport, A. M., Z. J. Borowy, W. M. Lougheed, and W. N. Lotto. 1954. Subdivision of hexagonal liver lobules into a structural and functional unit. Role in hepatic physiology and pathology. Anat. Rec. 119:11-33. https://doi.org/10.1002/ar.1091190103.

Rehage, J., M. Mertens, N. Stockhofe-Zurwieden, M. Kaske, and H. Scholz. 1996. Post surgical convalescence of dairy cows with left abomasal displacement in relation to fatty liver. Schweiz. Arch. Tierheilkde 138:361-368.

Reid, I. M. 1980. Incidence and severity of fatty liver in dairy cows. Vet. Rec. 107:281-284. https://doi.org/10.1136/vr.107.12.281.

Reid, I. M., and R. A. Collins. 1980. The pathology of post-parturient fatty liver in high-yielding dairy cows. Invest. Cell Pathol. $3: 237-249$

Reid, I. M., A. J. Stark, and R. N. Isenor. 1977. Fasting and refeeding in the lactating dairy cow: 1 . The recovery of milk yield and blood chemistry following a six-day fast. J. Comp. Pathol. 87:241-251. https://doi.org/10.1016/0021-9975(77)90011-1.

Riedelsheimer, B., and S. Büchl-Zimmermann. 2015. Färbungen. Pages 171-282 in Romeis - Mikroskopische Technik. M. Mulisch, and U. Welsch, ed. 19th ed. Spektrum Akademischer Verlag.

Rothuizen, J., and T. S. van den Ingh. 1998. Hepatitis bij de hond; een overzicht. Tijdschr. Diergeneeskd. 123:246-252. [in Dutch]

Rukkwamsuk, T., T. A. Kruip, G. A. Meijer, and T. Wensing. 1999. Hepatic fatty acid composition in periparturient dairy cows with fatty liver induced by intake of a high energy diet in the dry period. J. Dairy Sci. 82:280-287. https://doi.org/10.3168/jds.S0022 -0302(99)75234-3.

Sangsritavong, S., D. K. Combs, R. Sartori, L. E. Armentano, and M. C. Wiltbank. 2002. High feed intake increases liver blood flow and metabolism of progesterone and estradiol-17 $\beta$ in dairy cattle. J. Dairy Sci. 85:2831-2842. https://doi.org/10.3168/jds.S0022 -0302(02)74370-1.

Schaffer, J. E. 2003. Lipotoxicity: When tissues overeat. Curr. Opin. Lipidol. 14:281-287. https://doi.org/10.1097/00041433-200306000 $-00008$

Schaffner, F., T. Barka, and H. Popper. 1963. Hepatic mesenchymal cell reaction in liver disease. Exp. Mol. Pathol. 2:419-441. https:/ /doi.org/10.1016/0014-4800(63)90020-0.

Schären, M., B. Riefke, M. Slopianka, M. Keck, S. Gruendemann, J. Wichard, N. Brunner, S. Klein, T. Snedec, K. B. Theinert, F. Pietsch, F. Rachidi, G. Köller, E. Bannert, J. Spilke, and A. Starke. 2021a. Aspects of transition cow metabolomics-Part III: Alterations in the metabolome of liver and blood throughout the transi- 
tion period in cows with different liver metabotypes. J. Dairy Sci. 104:9245-9262. https://doi.org/10.3168/jds/2020-19056.

Schären, M., T. Snedec, B. Riefke, M. Slopianka, M. Keck, S. Gruendemann, J. Wichard, N. Brunner, S. Klein, K. B. Theinert, F. Pietsch, A. Leonhardt, S. Theile, F. Rachidi, A. Kaiser, G. Köller, E. Bannert, J. Spilke, and A. Starke. 2021b. Aspects of transition cow metabolomics - Part I: Effects of a metaphylactic butaphosphan and cyanocobalamin treatment on the metabolome in liver, blood, and urine in cows with different liver metabotypes. J. Dairy Sci. 104:9227-9244. https://doi.org/10.3168/jds.2020-19057.

Sell, S. 1994. Liver stem cells. Mod. Pathol. 7:105-112.

Starke, A., A. Haudum, R. Busche, M. Beyerbach, S. Dänicke, and J. Rehage. 2010. Technical note: Analysis of total lipid and triacylglycerol content in small liver biopsy samples in cattle. J. Anim. Sci. 88:2741-2750. https://doi.org/10.2527/jas.2009-2599.

Starke, A., S. Schmidt, A. Haudum, T. Scholbach, P. Wohlsein, M. Beyerbach, and J. Rehage. 2011. Evaluation of portal blood flow using transcutaneous and intraoperative Doppler ultrasonography in dairy cows with fatty liver. J. Dairy Sci. 94:2964-2971. https:// doi.org/10.3168/jds.2011-4156.

Stöber, M., and H. Scholz. 1991. Treatment of dairy cow for lipomobilisation syndrome. Monatshefte Veterinarmedizin 46:563-566.

Sultana, N., and N. Q. Hanif. 2009. Mycotoxin contamination in cattle feed and feed ingredients. Pak. Vet. J. 29:211-213.
Suriyasathaporn, W., C. Heuer, E. N. Noordhuizen-Stassen, and Y. H. Schukken. 2000. Hyperketonemia and the impairment of udder defense: A review. Vet. Res. 31:397-412. https://doi.org/10.1051/ vetres:2000128

Tharwat, M., A. Takamizawa, Y. Z. Hosaka, D. Endoh, and S. Oikawa. 2012. Hepatocyte apoptosis in dairy cattle during the transition period. Can. J. Vet. Res. 76:241-247.

Vels, L., C. M. Røntved, M. Bjerring, and K. L. Ingvartsen. 2009. Cytokine and acute phase protein gene expression in repeated liver biopsies of dairy cows with a lipopolysaccharide-induced mastitis J. Dairy Sci. 92:922-934. https://doi.org/10.3168/jds.2008-1209.

Walther, T. C., and R. V. Farese Jr.. 2012. Lipid droplets and cellular lipid metabolism. Annu. Rev. Biochem. 81:687-714.

Weber, C., C. Hametner, A. Tuchscherer, B. Losand, E. Kanitz, W. Otten, S. P. Singh, R. M. Bruckmaier, F. Becker, W. Kanitz, and H. M. Hammon. 2013. Variation in fat mobilization during early lactation differently affects feed intake, body condition, and lipid and glucose metabolism in high-yielding dairy cows. J. Dairy Sci. 96:165-180. https://doi.org/10.3168/jds.2012-5574.

West, H. J. 1990. Effect on liver function of acetonaemia and the fat cow syndrome in cattle. Res. Vet. Sci. 48:221-227. https://doi.org/ 10.1016/S0034-5288(18)30994-9. 
Pietsch et al.: TRANSITION COW METABOLOMICS-PART II

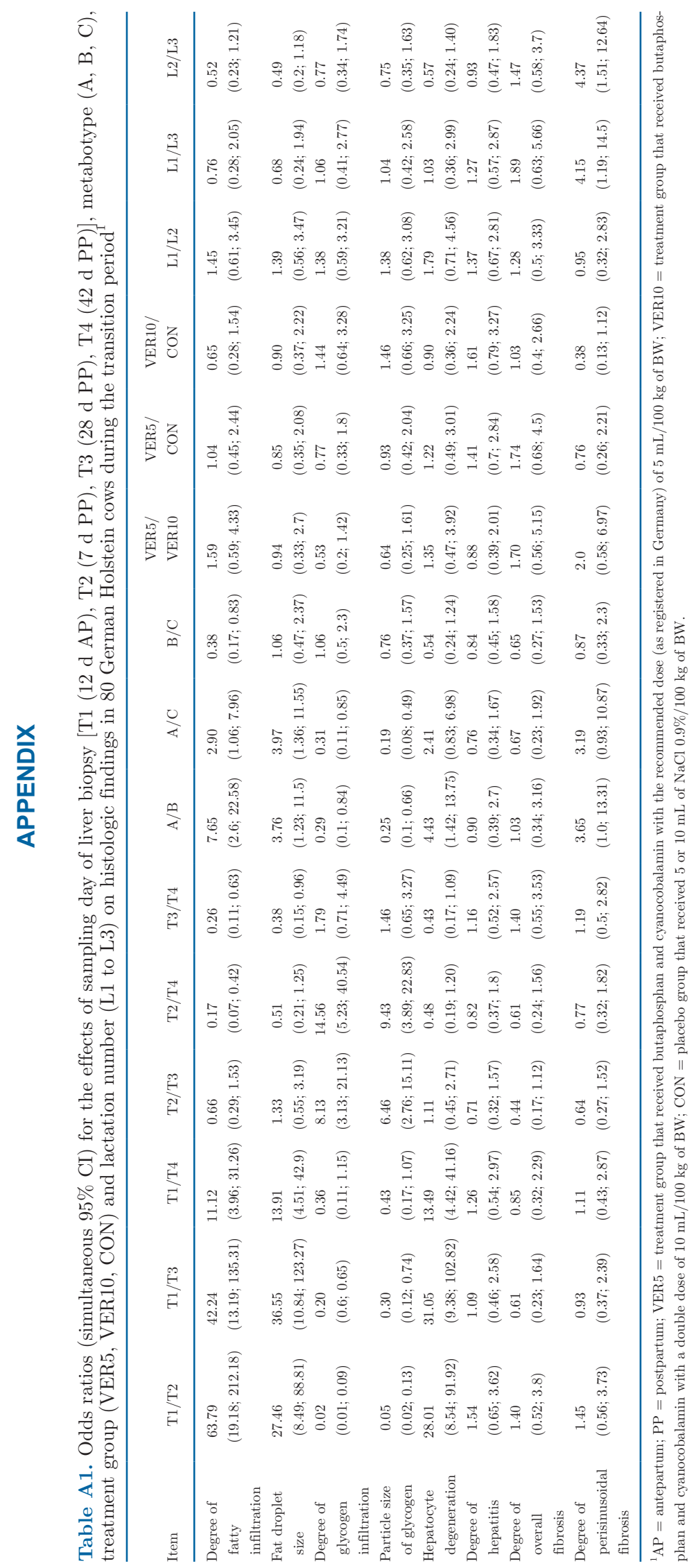


Table A2. Spearman rank correlation coefficients and $P$-values for the overall amount and the amounts in the metabotype (for details see Statistical Analysis section) in the histologic examination of the liver of 80 German Holstein cows during the transition period

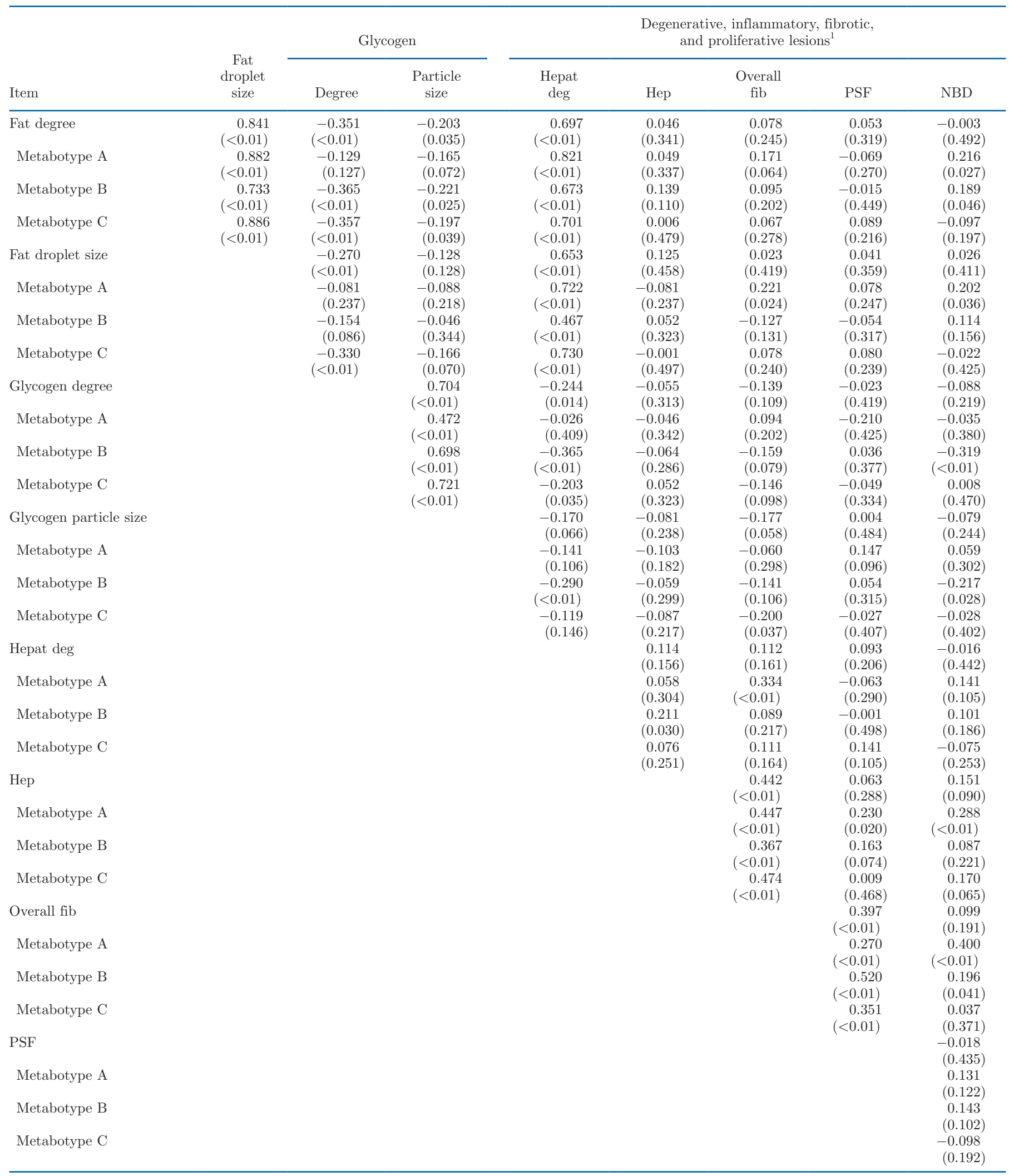

${ }^{1}$ Hepat $\operatorname{deg}=$ hepatocyte degeneration; Hep = degree of hepatitis; Overall fib = overall fibrosis; PSF = degree of perisinusoidal fibrosis; NBD = number of bile ducts. 